\title{
Key drivers of pyrogenic carbon redistribution during a simulated rainfall event
}

\author{
Severin-Luca Bellè ${ }^{1}$, Asmeret Asefaw Berhe ${ }^{2}$, Frank Hagedorn ${ }^{3}$, Cristina Santin ${ }^{4,5}$, Marcus Schiedung ${ }^{1}$, \\ Ilja van Meerveld ${ }^{1}$, and Samuel Abiven ${ }^{1,6,7}$ \\ ${ }^{1}$ Department of Geography, University of Zurich, Winterthurerstrasse 190, 8057 Zurich, Switzerland \\ ${ }^{2}$ School of Natural Sciences, University of California, Merced, CA 95340, USA \\ ${ }^{3}$ Forest soils and Biogeochemistry, Swiss Federal Research Institute WSL, Zürcherstrasse 111, \\ 8903 Birmensdorf, Switzerland \\ ${ }^{4}$ Department of Biosciences, College of Science, Swansea University, Swansea, UK \\ ${ }^{5}$ Research of Biodiversity (CSIC, UO, PA), University of Oviedo, Mieres, Spain \\ ${ }^{6}$ Laboratoire de Géologie, Département de Géosciences, CNRS - École normale supérieure, PSL University, Institut Pierre \\ Simon Laplace, Rue Lhomond 24, 75005 Paris, France \\ ${ }^{7}$ CEREEP-Ecotron Ile De France, ENS, CNRS, PSL University, Chemin de busseau 11, \\ 77140 St-Pierre-lès-Nemours, France
}

Correspondence: Samuel Abiven (abiven@biotite.ens.fr)

Received: 30 September 2020 - Discussion started: 2 November 2020

Revised: 4 January 2021 - Accepted: 7 January 2021 - Published: 15 February 2021

\begin{abstract}
Pyrogenic carbon (PyC) is produced by the incomplete combustion of vegetation during wildfires and is a major and persistent pool of the global carbon (C) cycle. However, its redistribution in the landscape after fires remains largely unknown. Therefore, we conducted rainfall simulation experiments on $0.25 \mathrm{~m}^{2}$ plots with two distinct Swiss forest soils (Cambisol (clay loam) and Luvisol (sandy silt)). We applied PyC produced from wood (Picea abies) labeled under FACE conditions and $\mathrm{C}_{4}$ grass (Miscanthus sinensis) to the soil surface to study PyC redistribution by runoff and splash and the vertical mobility of PyC in a $10 \mathrm{~cm}$ unsaturated soil column based on the differences in $\delta^{13} \mathrm{C}$ of soils and PyC. We assessed the effect of soil texture, slope angle and $\mathrm{PyC}$ characteristics (feedstock and particle size) on the mobility of $\mathrm{PyC}$ during $30 \mathrm{~min}$ of intense rainfall $\left(102 \mathrm{~mm} \mathrm{~h}^{-1}\right)$. Our results highlight that PyC is highly mobile. Surface runoff transported between $0.2 \%$ and $36.0 \%$ of the total added PyC. Erosion by splash further redistributed $10.3 \%$ to $25.3 \%$ of the added PyC. Soil type had a substantial impact on the redistribution of $\mathrm{PyC}$ by both runoff and splash: on average, we recovered $10.5 \%$ of the added PyC in runoff and splashed material for the clay-rich Cambisol and $61.3 \%$ of the added PyC for the sandy silt Luvisol combined.
\end{abstract}

PyC feedstock had a clear but contrasting effect on PyC redistribution: relocation in the runoff and splashed material was greater for wood $\mathrm{PyC}(43.4 \%$ of total added $\mathrm{PyC})$ than grass PyC (28.4\%). However, more wood PyC (11.5\%; fraction of organic $\mathrm{C}$ derived from the $\mathrm{PyC}$ ) remained where it was initially applied compared to grass PyC (7.4\%). The results further suggest that the effect of $\mathrm{PyC}$ characteristics on its mobility can be highly variable and depend not only on the material from which it was derived, but also on other factors (e.g., particle size, porosity, density). In particular, the mobility of PyC was almost twice as large for fine-grained PyC $(<63 \mu \mathrm{m})$ than for coarse PyC $(63 \mu \mathrm{m}-2 \mathrm{~mm})$. Vertical mobility of PyC up to $10 \mathrm{~cm}$ depth was greater in the clayrich, well-aggregated Cambisol but limited in the physically instable Luvisol, likely due to quick aggregate breakdown and surface sealing. The addition of PyC to the surface of the studied soils further induced changes in the export of native soil organic carbon (nSOC) after the 30 min rainfall event. Our study shows that large quantities of PyC can be redistributed by water erosion over short timescales and that the mobility of PyC depends to a great extent on the response of soils to rainfall. Moreover, the addition and redistribution 
of PyC affects the export of nSOC and thus the $\mathrm{C}$ budget of fire-affected soils and catchments.

\section{Introduction}

Wildfires burn 345 to 464 Mha, i.e., $4 \%$ of vegetated land area, annually and are thus a major disturbance for terrestrial ecosystems (Giglio et al., 2013; Randerson et al., 2012). The associated carbon (C) flux of $2.2 \mathrm{Pg}$ to the atmosphere affects the global $\mathrm{C}$ cycle and the Earth's climate (Bowman et al., 2009; van der Werf et al., 2017). It is predicted that fire frequencies will increase in many regions around the world due to climate change. This amplifies the importance of fires for key biogeochemical and climate processes and its correct representation in Earth system models (Conard and Solomon, 2008; Lasslop et al., 2019; Westerling et al., 2006). In addition to the impact on atmospheric $\mathrm{C}$ emissions, wildfires also affect the global $\mathrm{C}$ cycle through the impact on the Earth's surface processes (Lasslop et al., 2019). The incomplete combustion of vegetation during fires produces a continuum of C-rich materials with polycyclic, condensed aromatic molecular structures, ranging from soot to macroscopic charcoal (Bird et al., 2015; Hammes and Abiven, 2013). The global production of this fire-derived or pyrogenic C (PyC) is estimated to be 192 to $340 \mathrm{Tg}$ PyC annually (Jones et al., 2019; Santín et al., 2016). PyC is environmentally more resistant than its unburnt precursors and can remain in terrestrial and aquatic ecosystems for decades to millennia (Abiven and Santín, 2019; Coppola and Druffel, 2016; Santín et al., 2016). It is one of the largest and oldest C pools on Earth (Bird et al., 2015) and globally accounts for around $15 \%$ of organic carbon (OC) in soils (Reisser et al., 2016). However, we currently have little knowledge about the fate of $\mathrm{PyC}$ in the landscape, and the dominant processes that lead to its mobilization, degradation and stabilization at different landscape positions and at the interface between land and ocean still need to be clarified (Abiven and Santín, 2019; Abney and Berhe, 2018; Masiello and Berhe, 2020).

Erosion by water represents a fundamental transport process for soil organic carbon (SOC) and $\mathrm{PyC}$ in terrestrial sloping landscapes and determines its export to aquatic systems (Abney and Berhe, 2018; Berhe et al., 2018). Water erosion refers here to the detachment of particles by raindrop impact, subsequent transport by water and final deposition (Berhe et al., 2018; Doetterl et al., 2016). It takes place as splash erosion, interrill erosion, and rill-gully erosion (de Nijs and Cammeraat, 2020). Erosion globally causes the redistribution of 10 to $140 \mathrm{Pg}$ of soil per year (Berhe et al., 2018; Doetterl et al., 2016). Estimates of global SOC erosion range between 0.3 and $5 \mathrm{Pg} \mathrm{yr}^{-1}$ (Berhe et al., 2007; Chappell et al., 2016; Lal, 2004; Stallard, 1998). For PyC it has been estimated to be between 3 and $5 \mathrm{Tg} \mathrm{yr}^{-1}$ based on field investigations in Mediterranean climate (Abney et al., 2017) and 29 to $87 \mathrm{Tg} \mathrm{yr}^{-1}$ based on modeling of global PyC dynamics (Bird et al., 2015). The diverse methods used to quantify $\mathrm{PyC}$ contribute to the large variability in reported values of PyC erosion. Physical (based on size and density of $\mathrm{PyC}$ ), chemical (based on the oxidation resistance of PyC), thermal (based on temperature resistance of PyC), spectroscopic (based on magnetic or photonic response of PyC to input signal) and molecular marker (based on identification of PyC specific compounds) methods cover different windows of the PyC continuum, and, therefore, estimates of PyC movement in the landscape can vary substantially (Bird et al., 2015; Hammes and Abiven, 2013).

Erosion by water can have a profound impact on the persistence and fate of SOC and PyC as it can transfer these forms of $\mathrm{OC}$ from eroding landscapes to depositional sites where they can be preserved for a long time (Abney et al., 2017; Abney and Berhe, 2018). However, it can also accelerate decomposition of SOC and PyC by physical disintegration (Abney et al., 2019b; Pignatello et al., 2015) and biochemical degradation during and after transport (Hilscher and Knicker, 2011; Singh et al., 2012). Although it was debated in the past if erosion by water is a net $\mathrm{C}$ sink or source (Doetterl et al., 2016), it is today considered to be a $C$ sink. However, the size of the erosion-induced $\mathrm{C}$ sink still needs to be assessed (Abney and Berhe, 2018; Berhe et al., 2018).

In post-fire landscapes erosion by water is very often substantially enhanced (Abney and Berhe, 2018; Masiello and Berhe, 2020; Vieira et al., 2018). The removal of the protective vegetation cover during wildfires increases the impact of raindrops on the soil surface (Certini, 2005; Johansen et al., 2001; Pierson et al., 2013), which can cause aggregate breakdown and surface sealing (Moody et al., 2013; Shakesby, 2011). The effects of fire-induced changes on the structural and hydrological properties of soils and erosion depend on the fire regime (frequency, severity, intensity and extent), precipitation pattern (timing, frequency, intensity, watershed hydrology), vegetation (fuel load, ground cover, regrowth dynamics), topography (slope steepness, aspect, and length, micro-topography) and soil properties (texture, aggregation, saturation) (Abney and Berhe, 2018; Archibald et al., 2013; Berhe et al., 2012; Moody et al., 2013; Rumpel et al., 2015; Shakesby and Doerr, 2006). Soil type determines the extent to which erodible materials are susceptible to detachment and mobilization and, together with the local geomorphology, governs soil physical stability and therefore erodibility (Moody et al., 2013; Vieira et al., 2015).

The PyC particles produced during a fire that remain on the soil surface may be more redistributed by water erosion during the first rainfall than other soil particles (Abney et al., 2019a; Rumpel et al., 2006, 2009). This high mobilization of PyC is partially caused by its physical properties, in particular its low density and high porosity, but also due to the lack of organo-mineral interactions between the PyC and soil matrix that prevent either washout (surface erosion by interrill or splash) or washin (to deeper soil horizons) during ini- 
tial rainfall (Brewer et al., 2014; Masiello and Berhe, 2020; Pyle et al., 2017). Most PyC materials have a high initial hydrophobicity, which can promote floating and transport by water (Abney and Berhe, 2018; Rumpel et al., 2015). The transport of $\mathrm{PyC}$ also depends on the material from which it was derived, with grass-derived $\mathrm{PyC}$ being perceived to be more mobile than wood PyC (Saiz et al., 2018). Here, the physical stability of PyC plays a role: PyC that can be fragmented more easily will produce smaller particles (Pignatello et al., 2015; Saiz et al., 2018) that are more mobile (Masiello, 2004; Saiz et al., 2018; Santín et al., 2016). This fragmentation depends on the transformation of cell structures during pyrolysis, and it is usually higher for grass than for wood materials (Chrzazvez et al., 2014).

The combined effects of climate, vegetation, fire, catchment topography and hydrology, soils, and $\mathrm{PyC}$ properties will result in spatially variable post-fire redistribution of $\mathrm{PyC}$ (Abney and Berhe, 2018; Berhe et al., 2018; Moody et al., 2013). However, to which extent these drivers affect the magnitude of post-fire $\mathrm{PyC}$ erosion and deposition still needs to be elucidated (Abney and Berhe, 2018; Berhe et al., 2018; Santín et al., 2016). It is difficult to assess the redistribution of PyC directly after a fire because substantial redistribution occurs during the first major rainfall event (Masiello and Berhe, 2020). Rainfall simulation experiments allow controllability and comparability between drivers, so that a diverse set of drivers can be repeatedly studied from a mechanistic point of view under the same conditions (Doetterl et al., 2016; Rumpel et al., 2015). Furthermore, it is crucial to study individual transport processes of $\mathrm{PyC}$ in closed systems where $\mathrm{PyC}$ redistribution can be assessed fully with a single, direct tracer method that allows for sufficient replication under the same controlled conditions.

The objectives of this study were to assess the initial redistribution of PyC during major rainfall events on soils through splash and runoff as well as its vertical movement in the soil column and how this depends on soil texture, slope angle and $\mathrm{PyC}$ characteristics (feedstock and particle size). Therefore, we conducted a simulated rainfall experiment on $0.25 \mathrm{~m}^{2}$ soil plots on which wood and grass $\mathrm{PyC}$ with a different isotopic signal $\left(\delta^{13} \mathrm{C}\right)$ than the soils was applied. We estimated PyC redistribution by collecting it in the runoff sediment, splashed sediment, floating particles and soil cores and by measuring the relative contribution of $\mathrm{PyC}$ to the $\delta^{13} \mathrm{C}$ signal of the sediments, floating particles and soil cores. Specifically, we determined (a) the effect of soil texture, slope angle and $\mathrm{PyC}$ characteristics on the transport of PyC by surface runoff (i.e., overland flow); (b) the effect of soil texture, slope angle and $\mathrm{PyC}$ characteristics on $\mathrm{PyC}$ redistribution by splash; (c) the effect of soil texture, slope angle and $\mathrm{PyC}$ characteristics on the washin of PyC into the soil; and (d) the effect of the application of $\mathrm{PyC}$ on the redistribution of native soil organic carbon (nSOC).

\section{Material and methods}

\subsection{General approach}

We used rainfall simulation experiments to study PyC erosion and transport on soil plots. We used two forest soils with different properties (Sect. 2.2 and Table 1) that had been unburnt for at least 20 years and added wood or grass PyC (Sect. 2.3 and Table 2) to the surface of the uppermost third of the $0.25 \mathrm{~m}^{2}$ plot. We used a multi-factorial experimental design that included two elements of four key drivers of $\mathrm{PyC}$ relocation based on literature evidence. These included soil texture (clayey loam (Cambisol) vs. sandy silt (Luvisol)), slope angle $\left(10^{\circ}\right.$ vs. $\left.25^{\circ}\right), \mathrm{PyC}$ feedstock (wood PyC vs. grass PyC) and PyC particle size ( $<63 \mu \mathrm{m}$ vs. $63 \mu \mathrm{m}-2 \mathrm{~mm})$. Each of the two elements of the four drivers were combined and assessed in triplicates (48 plots). In addition, for soil texture and slope we also used four replicate control plots (16 plots) where no PyC was added (hereafter labeled as "CT"). During each experimental run, rainfall was applied for $30 \mathrm{~min}$ to one control plot and three plots where $\mathrm{PyC}$ was added. These were randomly selected (total 16 runs). The applied rainfall had an intensity of $102.8 \mathrm{~mm} \mathrm{~h}^{-1}(51.4 \pm 1.4 \mathrm{~mm}$ of applied rainfall in total). After the rainfall simulation ended, we collected the sediment that was transported by the runoff and the sediment that was splashed to the sides and, also, took soil cores to determine the redistribution of $\mathrm{PyC}$ across the plots and the vertical transport of $\mathrm{PyC}$ in the soil. We used the $\delta^{13} \mathrm{C}$ signal of the added $\mathrm{PyC}$ materials as a direct tracer of $\mathrm{PyC}$ in this study to overcome methodological limitations of other PyC detection methods.

\subsection{Soils}

We used the top $20 \mathrm{~cm}$ (without vegetation and litter) of two Swiss forest soils that differ in soil texture, soil stability, SOC content and soil hydrological properties (Table 1). The first soil is a Cambisol (IUSS Working Group WRB, 2015), collected from the Lägern site, next to the CarboEurope forest flux site (CH-LAE, $47^{\circ} 28^{\prime} 42.0^{\prime \prime} \mathrm{N}, 8^{\circ} 21^{\prime} 51.8^{\prime \prime} \mathrm{E}$ ), which is a site of the Long-term Forest Ecosystem Research (LWF) of the Swiss Federal Institute for Forest, Snow and Landscape Research (WSL). The site is located at $700 \mathrm{~m}$ a.s.l. on the Lägern mountain, which belongs to the Swiss Jura and is a mixed mountain forest dominated by beech, ash, fir, lime and spruce (Ruehr et al., 2010). It has a clayey loam texture, high aggregate stability (mean weight diameter $(\mathrm{MWD})=1.74 \pm 0.03)$ and SOC content of $3.6 \pm 0.4 \%$ (Table 1). The second soil is a Haplic Luvisol that was collected from the Möhlin site (Intercantonal Forest Observation Program in Switzerland). The Möhlin site is located on an alluvial deposit close to the river Rhine $\left(47^{\circ} 35^{\prime} 06.0^{\prime \prime} \mathrm{N}\right.$, $\left.7^{\circ} 52^{\prime} 34.3^{\prime \prime} \mathrm{E}\right)$ at an elevation of $290 \mathrm{~m}$ a.s.l. and is dominated by a woodruff beech forest stand (Braun et al., 2020). The soil has a sandy silt texture, medium aggregate stabil- 
Table 1. Total organic carbon (TOC), soil organic carbon stock (SOC), $\delta^{13} \mathrm{C}$, bulk density, soil texture, pH, aggregate stability (mean weight diameter (MWD)), runoff ratio (runoff / rainfall), and soil water repellency of the Cambisol and Luvisol. Average values \pm 1 standard error.

\begin{tabular}{|c|c|c|c|c|}
\hline & \multicolumn{2}{|c|}{ Cambisol } & \multicolumn{2}{|c|}{ Haplic Luvisol } \\
\hline TOC [\%] & \multicolumn{2}{|c|}{$3.6 \pm 0.4(n=72)$} & \multicolumn{2}{|c|}{$2.24 \pm 0.02(n=72)$} \\
\hline SOC stock $\left[\mathrm{Mg} \mathrm{ha}^{-1}\right]^{1}$ & \multicolumn{2}{|c|}{$36.0 \pm 4.0(n=72)$} & \multicolumn{2}{|c|}{$23.4 \pm 0.2(n=72)$} \\
\hline$\delta^{13} \mathrm{C}[\% o]$ & \multicolumn{2}{|c|}{$-29.07 \pm 0.05(n=72)$} & \multicolumn{2}{|c|}{$-29.87 \pm 0.03(n=72)$} \\
\hline Bulk density $\left[\mathrm{g} \mathrm{cm}^{-3}\right]$ & $\begin{array}{l}\text { Before rainfall } \\
0.94 \pm 0.03(n=4)\end{array}$ & $\begin{array}{l}\text { After rainfall } \\
1.01 \pm 0.03(n=4)\end{array}$ & $\begin{array}{l}\text { Before rainfall } \\
0.97 \pm 0.01(n=4)\end{array}$ & $\begin{array}{l}\text { After rainfall } \\
1.11 \pm 0.03(n=4)\end{array}$ \\
\hline
\end{tabular}

\begin{tabular}{|c|c|c|}
\hline Texture $[\%]$ & $\begin{array}{c}\text { Clay loam } \\
\text { Sand: } 45.5 \pm 3.5 \\
\text { Silt: } 24.2 \pm 4.4 \\
\text { Clay: } 31.5 \pm 2.4\end{array}$ & $\begin{array}{l}\text { Sandy silt } \\
\text { Sand: } 40 \\
\text { Silt: } 40 \\
\text { Clay: } 20\end{array}$ \\
\hline $\mathrm{pH}[-]$ & $5.9 \pm 0.5^{2}$ & $3.9^{3}$ \\
\hline Aggregate stability [MWD] & $1.74 \pm 0.03(n=6)$ & $0.89 \pm 0.03(n=6)$ \\
\hline $\begin{array}{l}\text { Runoff ratio }[\%]^{4} \\
{[\text { Runoff }(\mathrm{L}) / \text { rainfall }(\mathrm{mm})]}\end{array}$ & $\begin{array}{c}13.2 \pm 0.8(n=32) \\
(1.7 \pm 0.1 / 51.4 \pm 1.4)\end{array}$ & $\begin{array}{c}88.5 \pm 2.3(n=32) \\
(11.4 \pm 0.3 / 51.4 \pm 1.4)\end{array}$ \\
\hline Water repellency $^{5}$ & Very hydrophilic to hydrophilic $(n=5)$ & Very hydrophilic $(n=5)$ \\
\hline
\end{tabular}

Table 2. Total C, $\delta{ }^{13} \mathrm{C}$ and water repellency of wood PyC (derived from Picea abies) and grass PyC (derived from Miscanthus sinensis). Average values \pm 1 standard error.

\begin{tabular}{lll}
\hline & $\begin{array}{l}\text { Wood PyC } \\
\text { (Picea abies) }\end{array}$ & $\begin{array}{l}\text { Grass PyC } \\
\text { (Miscanthus sinensis) }\end{array}$ \\
\hline Total C [\%] & $64.9 \pm 1.3(n=5)$ & $68.6 \pm 1.8(n=5)$ \\
$\delta^{13} \mathrm{C}[\% \circ]$ & $-38.2 \pm 0.2(n=5)$ & $-13.8 \pm 0.1(n=5)$ \\
Water repellency* $^{*}$ & Extremely hydrophobic $(n=5)$ & Extremely hydrophobic $(n=5)$ \\
\hline
\end{tabular}

${ }^{*}$ According to classification by Doerr (1998).

ity (MWD $=0.89 \pm 0.03)$ and SOC content of $2.24 \pm 0.02 \%$ (Table 1). In the following, the soils are named "Cambisol" and "Luvisol", respectively. The collected soils were kept indoor under a protective foil and regularly rewetted with deionized water prior to the experiments. The soils were not sieved to $<2 \mathrm{~mm}$ due to the considerable amount of soil material (approximately 1 metric ton of each soil). Even though a soil that had been burned on the surface would have been more realistic, we used unburnt soils for practical reasons (large volume of soils, homogeneity of the surface, reproducibility of fire conditions, control of initial PyC amount).

\subsection{Pyrogenic carbon (PyC) material: production and characterization}

We used two types of PyC material (Table 2): PyC from spruce wood (Picea abies, hereafter called wood PyC and labeled with "W") grown under FACE conditions (Free Air Carbon Dioxide Enrichment; Hagedorn et al., 2003) and PyC from Miscanthus grass (Miscanthus sinensis), a $\mathrm{C}_{4}$ plant (Hilber et al., 2012) (hereafter called grass PyC and labeled with "G"). The PyC was produced in several batches through pyrolysis, following the established method described in Hammes et al. (2006). Briefly, the biomass was loaded in a quartz tube (small chips of wood and grass of several centimeters in size), heated to $450{ }^{\circ} \mathrm{C}$ in a pyrolysis oven and charred for $4 \mathrm{~h}$ under a continuous $\mathrm{N}_{2}$ stream, and collected after cooling. Pyrolysis has little effect on the $\delta^{13} \mathrm{C}$ of PyC $(-38.0 \pm 0.2 \%$ o for spruce wood vs. $-38.2 \pm 0.2 \%$ o for wood PyC, and $-12.7 \pm 0.1 \%$ of for Miscanthus grass vs. $-13.8 \pm 0.1 \%$ o for grass $\mathrm{PyC}$ ). Mean mass recovery was $31.0 \pm 0.5 \%$, which is in line with yields reported by Keiluweit et al. (2010) for both grass and wood PyC at com- 
parable charring temperatures $\left(400\right.$ to $\left.500^{\circ} \mathrm{C}\right)$. Afterwards, we homogenized the $\mathrm{PyC}$ of all batches by carefully mixing them in a bowl. To produce two sizes of PyC particles, we first passed the PyC through a $2 \mathrm{~mm}$ sieve and retained it on a $63 \mu \mathrm{m}$ sieve to obtain the coarse particles $(63 \mu \mathrm{m}-2 \mathrm{~mm}$, hereafter labeled with "CP"). Afterwards, a subsample was milled and passed through the $63 \mu \mathrm{m}$ sieve (hereafter labeled with "FP"). Each of the two PyC particle size fractions was homogenized by mixing, and aliquots were sampled for characterization.

We determined PyC water repellency using the ethanol droplet test, as described in Doerr (1998). The wood and grass PyC were both extremely hydrophobic, with no detectable differences between them (Table 2). We characterized the PyC material by diffuse reflectance infrared Fouriertransformed spectroscopy (DRIFT) analysis (TENSOR 27 spectrophotometer, Bruker Fällanden, Switzerland). DRIFT spectra highlighted a higher aromaticity and condensation for the wood PyC, as indicated through higher absorption at $1730-1680 \mathrm{~cm}^{-1}$ assigned to carbonyl / carboxyl $\mathrm{C}=\mathrm{O}$ and at $1610-1570 \mathrm{~cm}^{-1}$ assigned to aromatic $\mathrm{C}=\mathrm{C}$ (Fig. S1). Cell structures were also better preserved for the wood $\mathrm{PyC}$ than the grass $\mathrm{PyC}$, as indicated by a higher absorption for cellulose (C-O) at $1260-1210 \mathrm{~cm}^{-1}$ (Chatterjee et al., 2012; Keiluweit et al., 2010).

\subsection{Plot preparation}

For the experiments, we used a soil plot $(0.5 \times 0.5 \times 0.2 \mathrm{~m}$; $0.25 \mathrm{~m}^{2}$ flume) and added clean Styrofoam (so that water can still drain) to the bottom $10 \mathrm{~cm}$. We added the soil on top of the Styrofoam to reach a soil thickness of 10-12 cm and slightly compressed it to avoid any bagging of soil during experiments (bulk density between 0.9 (Cambisol) and $1.0 \mathrm{~g} \mathrm{~cm}^{-3}$ (Luvisol)). We took particular care to also fill the edges of the plots and leveled the surface with a metal bar. We then applied the PyC material evenly on the surface of the uppermost third of the plot (upslope). The application rate was $118.7 \mathrm{~g} \mathrm{PyC} \mathrm{m}^{-2}$ (equal of $77.0 \pm 1.5 \mathrm{~g} \mathrm{C}$ for wood PyC (total $\mathrm{C}=64.9 \pm 1.3 \%$ ) and $81.4 \pm 2.1 \mathrm{~g} \mathrm{C}$ for grass PyC (total $\mathrm{C}=68.6 \pm 1.8 \%)$ ) and we let it settle for at least $1 \mathrm{~h}$ to simulate surface deposition (Fig. 1). We choose this application rate based on literature estimates of standing biomass per square meter and $\mathrm{PyC}$ production and post-fire deposition (Proulx et al., 2015; Santín et al., 2015) and application rates $\left(106 \mathrm{~g} \mathrm{~m}^{-2}\right)$ used in field plot studies on PyC erosion (Rumpel et al., 2009).

The surface of the prepared plots were photographed with a high-end Sony Alpha 7R III \& Zeiss Batis $18 \mathrm{~mm}$ fixed wide-angle lens ( $4 \mathrm{~K}$ resolution with pixel-shift technology) attached to a tripod (fixed distance and angle to the floor) (Fig. 1b). Prior to rainfall simulation, the plots were adjusted to the respective slope angle $\left(10^{\circ}\right.$ or $\left.25^{\circ}\right)$ and an overflow (metal plate) was added to the lowest sidewall and connected to a runoff channel and bucket (Fig. 1a). We monitored soil moisture in each plot with a Decagon Em50 (inserted at $5 \mathrm{~cm}$ depth). Finally, we installed the splash shelter (corrugated panel) around each plot to ensure a closed system (Fig. 1a). We are aware that the setup used in our study will underestimate the splash erosion component. Splash erosion will not only occur to the sides of the soil plots (captured with the shelter around it), but also on the plots themselves. This latter component of splash erosion will be counted as either runoff erosion if the material leaves the plot in the direction of slope or distribution of soil, SOC and PyC within the soil surface and plot mid- and downslope. Since the processes of splash and runoff erosion are linked, we need to bear in mind that part of the eroded material by runoff may be attributable to splash erosion. Still, our results are the best estimation we could get for the two processes.

\subsection{Rainfall simulation}

We used the indoor, gravity-type rainfall simulator at the Swiss Federal Institute for Forest, Snow and Landscape Research (WSL) for the rainfall simulation experiments. The simulator includes drop-producing needles with an inner diameter of $0.05 \mathrm{~mm}$ and a drop fall height of 7 to $8.5 \mathrm{~m}$. The setup and general principles of the simulator have been described in detail in Berger et al. (2010), and basic data (i.e., water pressure, flow, temperature, rainfall characteristics) can be found in the Supplement (Table S1 and Fig. S2). The simulator setup produced raindrops that reached terminal velocities and drop size distribution (determined using the oil method; Kathiravelu et al., 2016; data not shown) close to natural rainfalls (Abd Elbasit et al., 2010; Abudi et al., 2012; Aksoy et al., 2012). We used only one simulator element $(1.05 \times 3.25 \mathrm{~m})$ and a designated area of $0.8 \times 2.8 \mathrm{~m}$ under the simulator for the experiments. This allowed us to place four of the $0.25 \mathrm{~m}^{2}$ plots side by side below the simulator and apply rainfall to them simultaneously. The rainfall intensity in the simulation area was measured three times using 56 small $(8.5 \mathrm{~cm}$ diameter) funnel gauges (Fig. S2). The simulator produced constant rainfall of $102.8 \mathrm{~mm} \mathrm{~h}^{-1}(51.4 \pm 1.4 \mathrm{~mm}$ in $30 \mathrm{~min}$ ). The Christiansen uniformity coefficient of $84 \%$ indicates a uniform distribution of the rainfall over the simulation area (Aksoy et al., 2012; Christiansen, 1942; Lassu and Seeger, 2015).

Because we applied rainfall to four plots at a time, we prioritized homogeneous distribution of rainfall over the simulated area to ensure controlled and comparable conditions between the plots. The uniformity of the rainfall over the simulation area decreased rapidly with intensities smaller than $100 \mathrm{~mm} \mathrm{~h}^{-1}$, and therefore this intensity was chosen. The simulated rainfall depth of $51.4 \mathrm{~mm}$ for $30 \mathrm{~min}$ represents a rainfall event with a return interval of 51-206 years for three long-term meteorological stations near the Lägern site (Zurich Kloten: 206 (95\% confidence interval: 51 to $>300$ ), Zurich Affoltern: 69 (21 to > 300) and Zurich Fluntern: 93 $(25.5$ to $>300))$. For the stations in close proximity to the 


\section{Experimental setup}

\section{PyC surface dynamics}

(a)

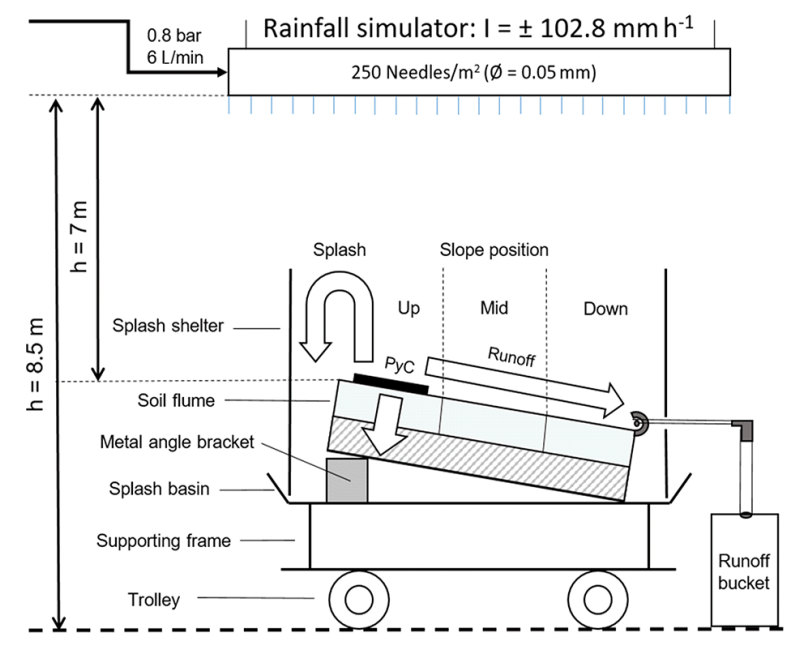

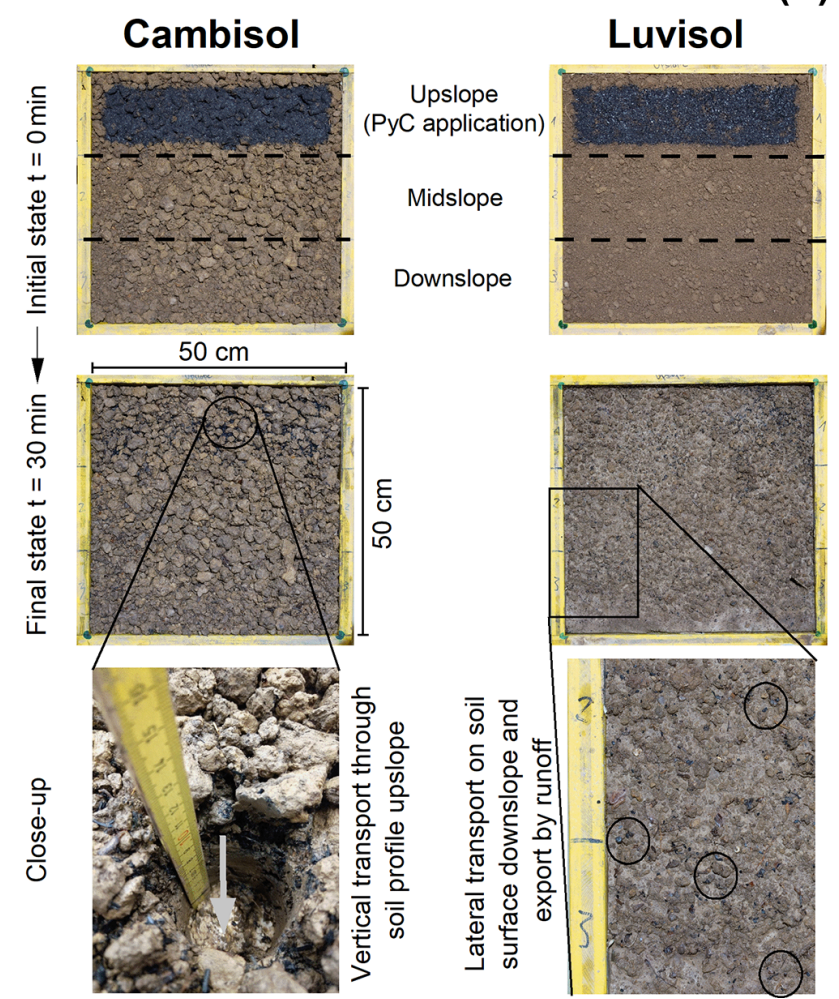

Figure 1. Experimental setup, including the rainfall simulator and an example of a $0.25 \mathrm{~m}^{2}$ soil plot (a) and visual assessment of the surface of the Cambisol and Luvisol $\left(25^{\circ}\right.$ slope and with coarse wood PyC) (b). Each $0.25 \mathrm{~m}^{2}$ soil plot was photographed before and after the 30 min rainfall simulation experiment. Visual assessment showed vertical movement of PyC in the Cambisol (white arrow in b) and surface redistribution of $\mathrm{PyC}$ on the Luvisol (black circles in $\mathbf{b}$ ).

Möhlin site, it represents an event with a return interval of 99-117 years (Rünenberg: 98.5 (25 to $>300$ ) and Basel: 116.5 (28 to > 300); 1982-2018 data, Federal Office of Meteorology and Climatology MeteoSwiss, 2019).

\subsection{Sampling, sample preparation and analysis}

After the rainfall simulation experiment, we flushed the runoff channel with a known volume of deionized water and recorded the total weight of the bucket that already contained the surface runoff and the eroded material. To collect splash sediment, we washed the splash panel with a known volume of deionized water and collected it in the splash basin that already contained the eroded splash material. We transferred all the collected splash material to a bucket and weighed it. The buckets with the runoff and splashed material were set aside for sedimentation for $>24 \mathrm{~h}$ before carefully collecting the particles floating on the water surface, pumping out the water with a bell jar attached to a peristaltic pump and finally collecting the sediment that settled at the bottom of the buckets. The sediment and floating particles of both the runoff and the splashed material were separately dried at $40{ }^{\circ} \mathrm{C}$ and weighed. Finally, sediment samples of both the runoff and splash were milled. The floating particles of both the runoff and splash were milled in a mortar by hand because of the small amount of material. The collected sediment and floating particles were analyzed for total organic carbon (TOC; representing $\mathrm{nSOC}$ for control plots and $\mathrm{nSOC}+\mathrm{PyC}$ for plots where $\mathrm{PyC}$ was applied) and $\delta^{13} \mathrm{C}$, relative to the international Vienna Pee Dee Belemnite (VPDB) standard, using cavity ring-down spectroscopy with a dry combustion system (CRDS Picarro, Inc. 2020).

Prior to sampling the soil after the experiment, each plot was photographed as described previously (i.e., similar to before the rainfall simulation). We sampled the soil with a soil corer (steel cylinder with $5 \mathrm{~cm}$ diameter and $10 \mathrm{~cm}$ length). We took cores at three random locations in the three slope positions (upslope, midslope, downslope), cut the cores into three depth increments $(0-1,1-3$ and $3-10 \mathrm{~cm})$ and homogenized the material from the three cores per depth to obtain one composite sample per slope position, depth and plot. Soil samples were air-dried, sieved to $<2 \mathrm{~mm}$ and milled. The 
soil samples were analyzed similarly as the collected sediment and floating particles for TOC and $\delta^{13} \mathrm{C}$. Additionally, we took cores from control plots for each soil before and after rainfall simulation and analyzed them for the bulk density. We also tested the aggregate stability (mean weight diameter (MWD) calculation) of the soils with the fast wetting method described in Le Bissonnais (2016). Using the same method as for PyC materials, we tested soil water repellence according to the ethanol droplet test of Doerr (1998).

\subsection{Quantification of the PyC contribution to TOC using $\delta^{13} \mathrm{C}$ and $\mathrm{C}$ recovery}

To determine $\mathrm{PyC}$ redistribution during a rainfall event, we used the differences in $\delta^{13} \mathrm{C}$ of the forest soils $(-29.1 \pm 0.1 \%$ or the Cambisol and $-29.9 \pm 0.1 \%$ for the Luvisol) and the PyC materials $(-38.2 \pm 0.2 \%$ for the wood $\mathrm{PyC}$ and $-13.8 \pm 0.1 \%$ or the grass $\mathrm{PyC}$ ). The $\delta^{13} \mathrm{C}$ difference of $8.3 \%-16.1 \%$ o between the soils and PyC materials was much larger than the maximal drift of the CRDS analyzer $(<0.5 \% \circ)$ and allowed us to differentiate between $\mathrm{nSOC}$ and $\mathrm{PyC}$ in the TOC. We used a two-pool isotopemixing model to calculate the contribution of the added PyC to the $\delta^{13} \mathrm{C}$ signal of a sample (sediment, floating particles or soil cores) using Eq. (1):

$f=1-\left(\frac{\left(\delta^{13} \mathrm{C}_{\text {sample }}-\delta^{13} \mathrm{C}_{\text {PyC_app }}\right)}{\left(\delta^{13} \mathrm{C}_{\text {control }}-\delta^{13} \mathrm{C}_{\text {PyC_app }}\right)}\right) \times 100$,

where $f$ is the fraction of OC derived from the PyC (or PyC fraction, \%), $\delta^{13} \mathrm{C}_{\text {sample }}$ is the $\delta^{13} \mathrm{C}$ value of the sample, $\delta^{13} \mathrm{C}_{\mathrm{PyC} \_ \text {app }}$ is the average $\delta^{13} \mathrm{C}$ value of the added PyC (Table 2) and $\delta^{13} \mathrm{C}_{\text {control }}$ is the average $\delta^{13} \mathrm{C}$ value of the control plots for the runoff, splashed sediments, runoff and splash floating particles (representing the nSOC of the TOC). The $\mathrm{PyC}$ fraction (\%) was subsequently multiplied with the TOC $(\mathrm{nSOC}+\mathrm{PyC}, \mathrm{g})$, and finally the quantity of $\mathrm{PyC}(\mathrm{g} \mathrm{C})$ was divided by the amount of added PyC ( $\mathrm{g} \mathrm{C}$ ) to calculate $\mathrm{PyC}$ recovery ( $\%$ of total added PyC). For the soil core calculations (Fig. 6 and Table S2), we used the average $\delta^{13} \mathrm{C}$ value of all control samples (Table 1) to ensure a stable background signal to calculate the PyC fraction. For the soil core samples, we could not convert the $\mathrm{PyC}$ fraction to a reliable $\mathrm{PyC}$ recovery value because both the soil mass and the TOC contents of the soil core samples were too variable.

\subsection{Statistical analyses}

We ran Levene's test to check the homogeneity of variance assumption (center is equal to the mean). We ran a two-way ANOVA model for the full dataset on eroded soil mass, eroded TOC, PyC recovery (runoff and splash sediment, runoff and splash floating particles) and subsequently a two-way ANOVA model per soil type (Cambisol and Luvisol) for the same datasets. For the soil core data, we used a two-way ANOVA model for each slope position (upslope, midslope and downslope) and depth increment $(0-1,1-3$, $3-10 \mathrm{~cm}$ ) for the full dataset and subsequently for the individual soil types. We used the Shapiro-Wilk tests on the ANOVA residuals to check the normality assumption and Fisher's least significant difference (LSD) post-hoc tests (alpha $=0.05$, $\mathrm{p} . \mathrm{adj}=$ Bonferroni) on the two elements of the four drivers. For changes in nSOC export after application of PyC compared to corresponding controls, we used a Welch two-sample $t$-test (95\% confidence interval). All statistical analyses were completed using the R packages "agricolae" and "car" in RStudio Version 3.5.2 (R Core Team, 2018).

\section{Results}

\subsection{Redistribution of soil and total organic carbon (TOC)}

\subsubsection{Amount of runoff and relocated quantities of soil and floating particles}

The amount of surface runoff generated was much less for the Cambisol than the Luvisol plots, with average runoff ratios for all plots of $13.2 \pm 0.8 \%$ and $88.5 \pm 2.3 \%$, respectively (Table 1). Soil moisture was higher in the Cambisol and for both soils for the $10^{\circ}$ plots than the $25^{\circ}$ plots (Fig. S3). For the Cambisol, initial soil moisture increased rapidly over the first $5 \mathrm{~min}$ and then steadily increased until the end of the rainfall simulation for both slope angles. For the Luvisol, soil moisture increased rapidly but less pronouncedly during the first $10 \mathrm{~min}$ and remained stable after $15 \mathrm{~min}$ for the $10^{\circ}$ slope plots and after around $20 \mathrm{~min}$ for the $25^{\circ}$ plots. The relatively low moisture contents of both soils at the end of the experiment and the flattening of the moisture curves towards the end of the simulation indicate that the soils were not fully saturated, and infiltration rates dropped due to surface sealing, especially for the Luvisol (Fig. S3). This was also visually observed during experiments.

The amount of soil that was transported by the runoff (i.e., the soil mass for control plots and soil + PyC mass for plots where PyC was applied) was significantly different for the two soil types: on average $1.3 \pm 0.2 \mathrm{~g}\left(=5.2 \pm 0.8 \mathrm{~g} \mathrm{~m}^{2}\right)$ for the Cambisol and 196.7 $\pm 14.3 \mathrm{~g}\left(=786.8 \pm 57.2 \mathrm{~g} \mathrm{~m}^{2}\right)$ for the Luvisol ( $p<0.001$; Fig. 2a). Note that because PyC represented $<2 \%$ of total mass, its influence on the total mass of transported soil could be neglected for this calculation. The runoff-driven erosion rates varied between $2.8 \pm 0.3 \mathrm{~g} \mathrm{~m}^{-2}$ (Cambisol under $10^{\circ}$ slope) and $1156.8 \pm 160.8 \mathrm{~g} \mathrm{~m}^{-2}$ (Luvisol under $25^{\circ}$ slope) for the $30 \mathrm{~min}$ rainfall simulation. The sediment transport was about 2 times higher for plots under steeper slopes (average for all $10^{\circ}$ plots: $70.4 \pm 13.6 \mathrm{~g}$ and all $25^{\circ}$ plots: $127.6 \pm 24.2 \mathrm{~g}$ ). The effect of slope was significant for the Cambisol $(p=0.03)$ and Luvisol $(p<0.001)$.

Soil type was also the main explanatory variable for the average amount of soil eroded by splash (Fig. 2b). It 


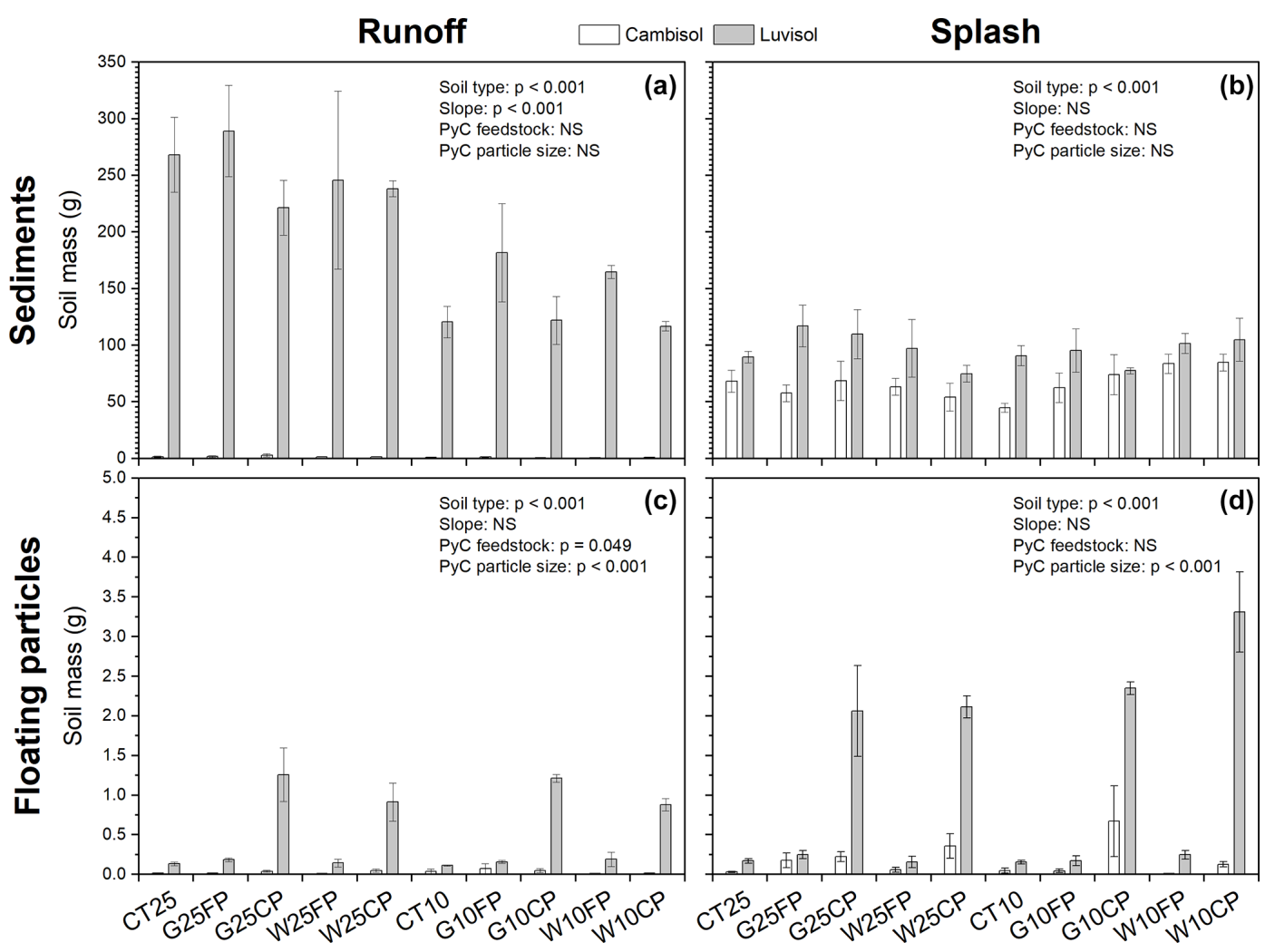

Figure 2. Amount of sediment (g) transported by the runoff (a) and splash (b) as well as floating particles transported by runoff (c) and splash (d) for each treatment after $30 \mathrm{~min}$ of rainfall (total: $51.4 \pm 1.4 \mathrm{~mm}$ ) (CT: control plots; G: grass PyC; W: wood PyC; $25: 25^{\circ}$ slope; 10: $10^{\circ}$ slope; FP: fine PyC $(<63 \mu \mathrm{m})$; CP: coarse PyC $(63 \mu \mathrm{m}$ to $\left.2 \mathrm{~mm})\right)$. Values are given as means $( \pm 1$ standard error) and correspond to the mass of soil for control plots (CT: $n=4)$ and mass of soil + PyC for plots where PyC was applied $(n=3$; PyC only represented $<2 \%$ of total mass).

was $31 \%$ less $(p<0.001)$ for the Cambisol $(65.5 \pm 3.6 \mathrm{~g}$ $\left.\left(=262.0 \pm 14.4 \mathrm{~g} \mathrm{~m}^{-2}\right)\right)$ than the Luvisol $(95.5 \pm 4.5 \mathrm{~g}$ $\left.\left(=382.0 \pm 18.0 \mathrm{~g} \mathrm{~m}^{-2}\right)\right)$. Transport rates by splash ranged between $178.8 \pm 16.0 \mathrm{~g} \mathrm{~m}^{-2}$ (Cambisol under $10^{\circ}$ slope) and $468.4 \pm 73.6 \mathrm{~g} \mathrm{~m}^{-2}$ (Luvisol under $25^{\circ}$ slope) for the $30 \mathrm{~min}$ rainfall simulation.

The total transport of floating particles (i.e., native SOC (nSOC) for control plots and nSOC $+\mathrm{PyC}$ for plots where PyC was applied) by runoff was different between soil types. It was $0.03 \pm 0.01 \mathrm{~g}$ for the Cambisol and $0.49 \pm 0.09 \mathrm{~g}$ for the Luvisol $(p<0.001)$. For PyC particle sizes, it was $0.6 \pm 0.1 \mathrm{~g}$ when PyC was applied as coarse particles $(\mathrm{CP})$, $0.09 \pm 0.02 \mathrm{~g}$ for fine particles (FP) and $0.08 \pm 0.02 \mathrm{~g}$ for controls (CT, no PyC applied) ( $p<0.001$; Fig. 2c). The mass of floating particles eroded by splash was larger than for the runoff and also dependent on soil type (Cambisol: $0.17 \pm 0.05 \mathrm{~g}$ and Luvisol: $1.0 \pm 0.2 \mathrm{~g}, p<0.001)$. It was further also dependent on PyC particle size (CP: $1.4 \pm 0.3 \mathrm{~g}$, FP: $0.14 \pm 0.02 \mathrm{~g}$ and CT: $0.10 \pm 0.02 \mathrm{~g}, p<0.001$; Fig. $2 \mathrm{~d}$ ). However, the total mass of floating particles transported by runoff or splash was only significantly higher with the application of coarse PyC to the Luvisol (significant interaction of the drivers "soil type $\times$ PyC particle size" in the ANOVA model: $p<0.001$ ).

\subsubsection{Transported TOC}

Similar to the mass of soil that was transported, the amount of TOC transported by runoff (i.e., native SOC (nSOC) for control plots and $\mathrm{nSOC}+\mathrm{PyC}$ for plots where $\mathrm{PyC}$ was added) was almost negligible for the Cambisol but notable for the Luvisol $(0.08 \pm 0.01 \mathrm{~g} \mathrm{C}$ and $7.3 \pm 0.5 \mathrm{~g} \mathrm{C}$, respectively, $p<0.001$, Fig. $3 a)$. Steeper slope angles $\left(25^{\circ}\right)$ resulted in $144 \%$ more TOC transport by the runoff but did not change the proportions of eroded TOC / soil. This effect holds true for both soil types (Cambisol $(p=0.03)$ and Luvisol $(p=0.0005)$ ). The strong interaction of soil type and slope in our model suggests that more TOC was transported by runoff on steeper slopes on the Luvisol in absolute terms ( $p=0.0003$; Fig. 3a). Transport rates of TOC by runoff ranged between $0.08 \pm 0.04 \mathrm{~g} \mathrm{C} \mathrm{m}^{-2}$ (Cambisol under $10^{\circ}$ slope) and $44.0 \pm 5.6 \mathrm{~g} \mathrm{C} \mathrm{m}^{-2}$ (Luvisol under $25^{\circ}$ slope) for the $30 \mathrm{~min}$ rainfall simulation. We found higher export of TOC (nSOC + PyC) by runoff when fine PyC particles (FP) were applied but not when coarse PyC particles 


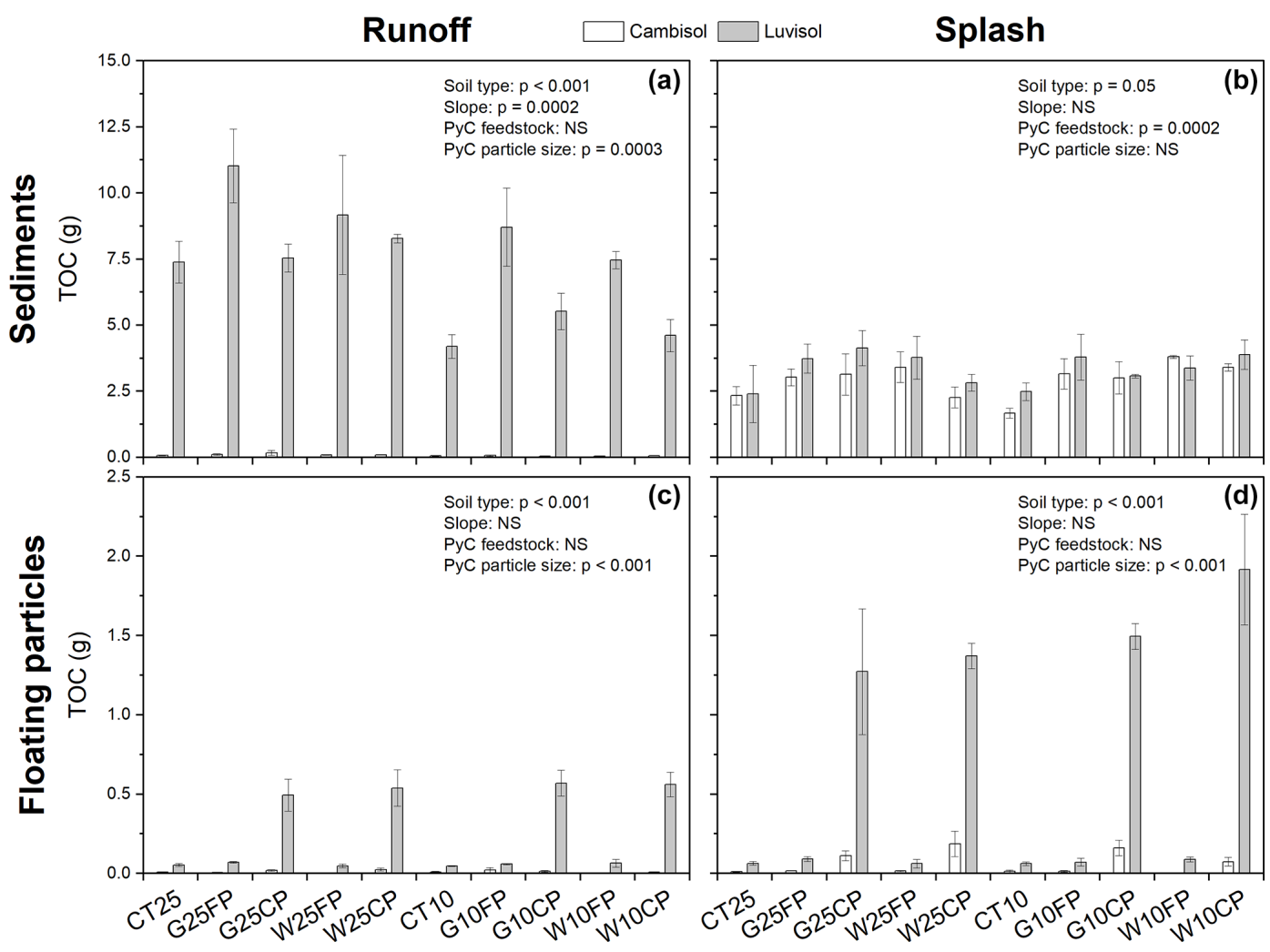

Figure 3. Amount of TOC (g) transported by runoff (a) and splash sediment (b) as well as the floating particles in runoff (c) and splash (d) for each treatment after $30 \mathrm{~min}$ of rainfall (total: $51.4 \pm 1.4 \mathrm{~mm})\left(\mathrm{CT}\right.$ : control plots; G: grass PyC; W: wood PyC; 25 : $25^{\circ}$ slope; 10 : $10^{\circ}$ slope; FP: fine PyC $(<63 \mu \mathrm{m})$; CP: coarse PyC $(63 \mu \mathrm{m}$ to $\left.2 \mathrm{~mm})\right)$. Values are given as means $( \pm 1$ standard error), and the TOC values represent native SOC (nSOC) for control plots (CT: $n=4)$ and $\mathrm{nSOC}+\mathrm{PyC}$ for plots where PyC was applied $(n=3)$.

(CP) were applied, compared to control plots (CT). However, we identified this only for the Luvisol (FP: $9.1 \pm 0.8 \mathrm{~g} \mathrm{C}$, CP: $6.5 \pm 0.5 \mathrm{~g} \mathrm{C}$ and CT (no PyC applied): $5.8 \pm 0.7 \mathrm{~g} \mathrm{C}$; $p=0.0009$ ), indicating that fine $\mathrm{PyC}$ particles preferentially contributed to the transported TOC by runoff on the Luvisol (soil type $\times$ PyC particle size: $p=0.003$; Fig. 3 a).

Splash erosion of TOC was slightly higher for the Luvisol (Cambisol: $2.9 \pm 0.2 \mathrm{~g} \mathrm{C}$ and Luvisol $3.3 \pm 0.2 \mathrm{~g} \mathrm{C}, p=0.05$; Fig. 3b). All plots of both soils receiving PyC showed higher splash erosion of TOC irrespective of PyC feedstock or particle size compared to control plots, but we found no difference between either wood and grass $\mathrm{PyC}$ or fine and coarse PyC for any of the soils (Fig. 3b). Transport rates of TOC through splash ranged between $6.8 \pm 0.8 \mathrm{~g} \mathrm{C} \mathrm{m}^{-2}$ (Cambisol under $10^{\circ}$ slope) and $16.4 \pm 2.8 \mathrm{~g} \mathrm{C} \mathrm{m}^{-2}$ (Luvisol under $25^{\circ}$ slope) for the $30 \mathrm{~min}$ rainfall simulation.

The transported quantities of TOC (i.e., nSOC for control plots and $\mathrm{nSOC}+\mathrm{PyC}$ for plots where $\mathrm{PyC}$ was applied) in the floating particles for both the runoff and splash differed between the soil types and PyC particle sizes (Fig. 3c-d). The mass of relocated TOC by runoff of floating particles was $0.011 \pm 0.002 \mathrm{~g} \mathrm{C}$ for the Cambisol and $0.24 \pm 0.04 \mathrm{~g} \mathrm{C}$ for the Luvisol $(p<0.001$; Fig. 3c). Application of both wood and grass PyC as coarse particles resulted in more transport of TOC in floating particles by runoff compared to the control plots, but this was not the case for the fine PyC particles. The particle size was significant for the Luvisol, but not the Cambisol, which suggests that the coarse PyC contributed to the transported TOC of floating particles in the runoff for the Luvisol (soil type $\times$ PyC particle size: $p<0.001$; Fig. 3c). The mass of TOC in floating particles relocated by splash erosion was $0.06 \pm 0.01 \mathrm{~g} \mathrm{C}$ for the Cambisol and $0.6 \pm 0.1 \mathrm{~g} \mathrm{C}$ for the Luvisol ( $p<0.001$; Fig. 3d). For both soils, application of wood and grass $\mathrm{PyC}$ as coarse particles resulted in more relocation of TOC in floating particles by splash compared to the controls, and again this was not the case for the fine PyC particles ( $p<0.001$; Fig. 3d).

\subsection{Redistribution of $\mathrm{PyC}$ by runoff and splash: recovery of added PyC}

We observed similar trends for the redistribution of the added $\mathrm{PyC}$ as for the transported soil and TOC (Figs. 2-3), including clear differences between the two soil types (Fig. 7). $\mathrm{PyC}$ relocation (as a percentage of total added $\mathrm{PyC}$ ) through runoff and splash erosion combined, for both sediment and floating particles, varied between $10.5 \pm 1.4 \%$ for the Cam- 


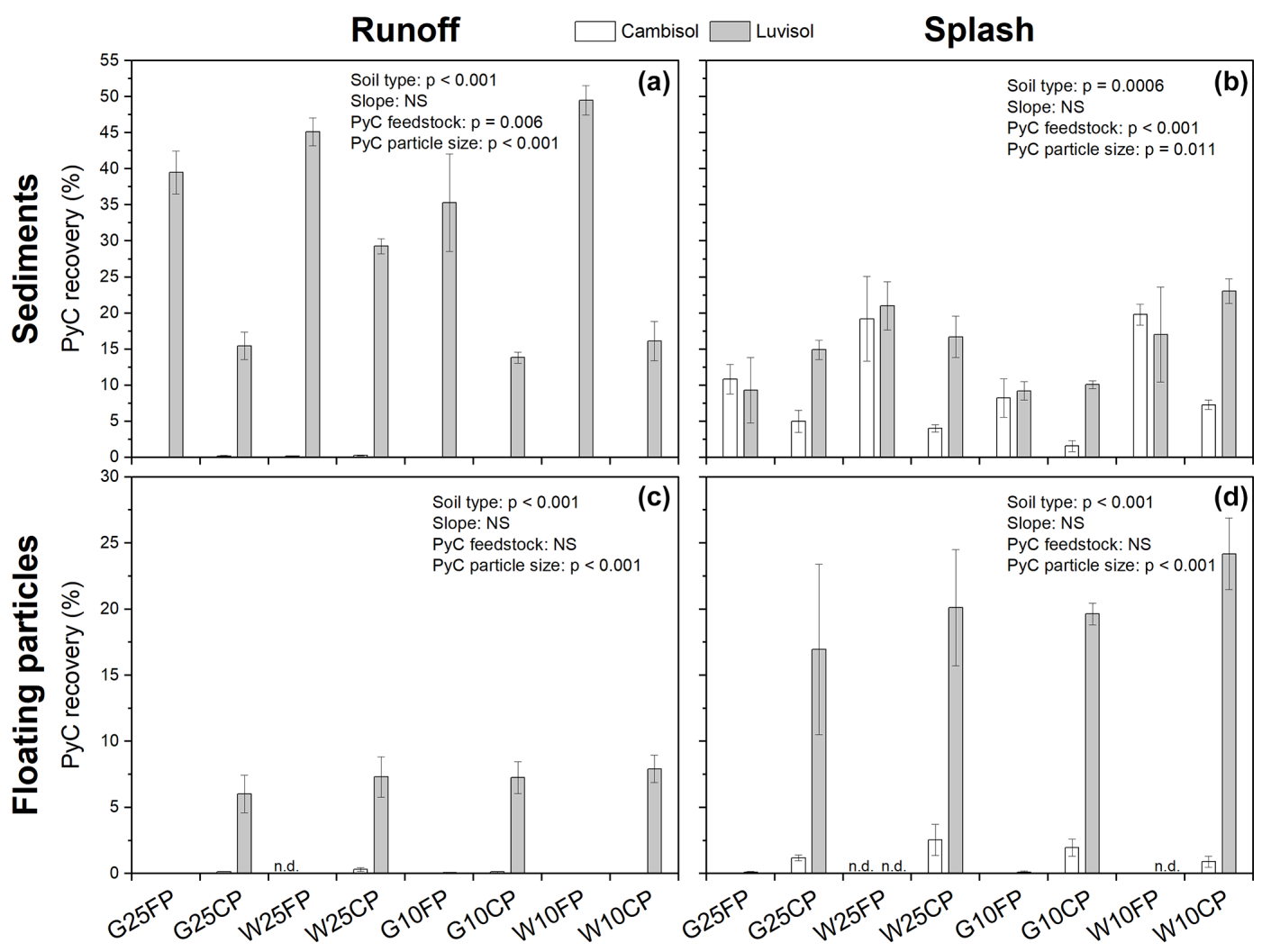

Figure 4. PyC recovery (\% of total added PyC) in sediment transported by runoff (a) or splash (b), and floating particles transported by runoff (c) and splash (d) for each treatment after $30 \mathrm{~min}$ of rainfall (total: $51.4 \pm 1.4 \mathrm{~mm}$ ) (G: grass PyC; W: wood PyC; $25: 25^{\circ}$ slope; 10 : $10^{\circ}$ slope; FP: fine PyC $(<63 \mu \mathrm{m})$; CP: coarse PyC $(63 \mu \mathrm{m}$ to $\left.2 \mathrm{~mm})\right)$. Average values \pm 1 standard error $(n=3)$.

bisol and $61.3 \pm 3.4 \%$ for the Luvisol $(p<0.001$; Figs. 4 and 7). Moreover, we recovered much more of the added $\mathrm{PyC}$ in the sediments and floating particles transported by runoff and splash combined after application of wood than grass PyC (W: $43.4 \pm 6.6 \%$ and G: $28.4 \pm 4.6 \%, p<0.001$; Fig. 4).

$\mathrm{PyC}$ in the runoff sediment (\% of total added PyC) was approximately 300 times more for the Luvisol $(32.4 \pm 3.8 \%)$ than the Cambisol $(0.09 \pm 0.02 \%, p<0.001$; Fig. 4a). Application of wood $\mathrm{PyC}$ resulted in more $\mathrm{PyC}$ relocation in sediment by runoff $(19.4 \pm 5.0 \%)$ compared to grass PyC $(13.1 \pm 3.3 \%)$, and this effect was significant for both soils (Cambisol: $p=0.04$ and Luvisol: $p=0.009$ ). Application of fine $\mathrm{PyC}(23.1 \pm 5.3 \%)$ resulted in more PyC redistribution of the sediment by runoff compared to coarse PyC particles $(9.4 \pm 2.2 \%)$ in the full ANOVA model, but the effect differed for the two soils (Fig. 4a). There was more PyC relocation for coarse particles for the Cambisol ( $p=0.01$; less than $<0.13 \pm 0.03 \%$ for both particle sizes), but, for the Luvisol, there was more $\mathrm{PyC}$ relocation for the fine particles (FP: $46.1 \pm 4.6 \%$ and CP: $18.7 \pm 2.0 \%, p<0.001$ ). In contrast to the amount of transported soil and TOC by the runoff (Figs. 2a and 3a), slope angle did not affect PyC redistribution ( $p=0.09$; Fig. 4a).
In accordance with the larger mass of splashed soil (Fig. 2b), we found greater PyC relocation (\% of total added PyC) by splash for the Luvisol $(15.2 \pm 1.4 \%)$ than the Cambisol $(9.5 \pm 1.5 \%, p=0.0006$; Fig. 4b). When averaged for the two soils, redistribution of PyC by splash was twice as much when wood PyC $(16.0 \pm 1.7 \%)$ was applied compared to grass PyC $(8.6 \pm 1.0 \%, p<0.001)$. Relocation of PyC by splash was greater when fine PyC particles were applied compared to coarser ones (FP: $14.3 \pm 1.6 \%$ and CP: $10.3 \pm 1.5 \%$ ), but this effect was only significant for the Cambisol (soil type $\times$ PyC particle size: $p<0.0003$; Fig. 4b).

Redistributed quantities of $\mathrm{PyC}$ as floating particles were significantly different for the two soil types and PyC particle sizes (Fig. 4c-d). Relocated PyC in floating particles in the runoff was $0.07 \pm 0.03 \%$ of initially added $\mathrm{PyC}$ for the Cambisol and $3.6 \pm 0.8 \%$ for the Luvisol $(p<0.001$; Fig. $4 c)$. Application of coarse $\mathrm{PyC}$ particles resulted in significantly higher relocation of $\mathrm{PyC}$ in floating particles in runoff compared to finer PyC (CP: $3.6 \pm 0.8 \%$ and FP: $0.02 \pm 0.01 \%$; Cambisol $(p=0.001)$ and Luvisol $(p<0.001)$; Fig. $4 c)$. Relocated $\mathrm{PyC}$ in floating particles of splash accounted for $0.8 \pm 0.2 \%$ (Cambisol) and $10.1 \pm 2.3 \%$ (Luvisol) of the recovered PyC $(p<0.001$; Fig. $4 d)$. The amount of relo- 


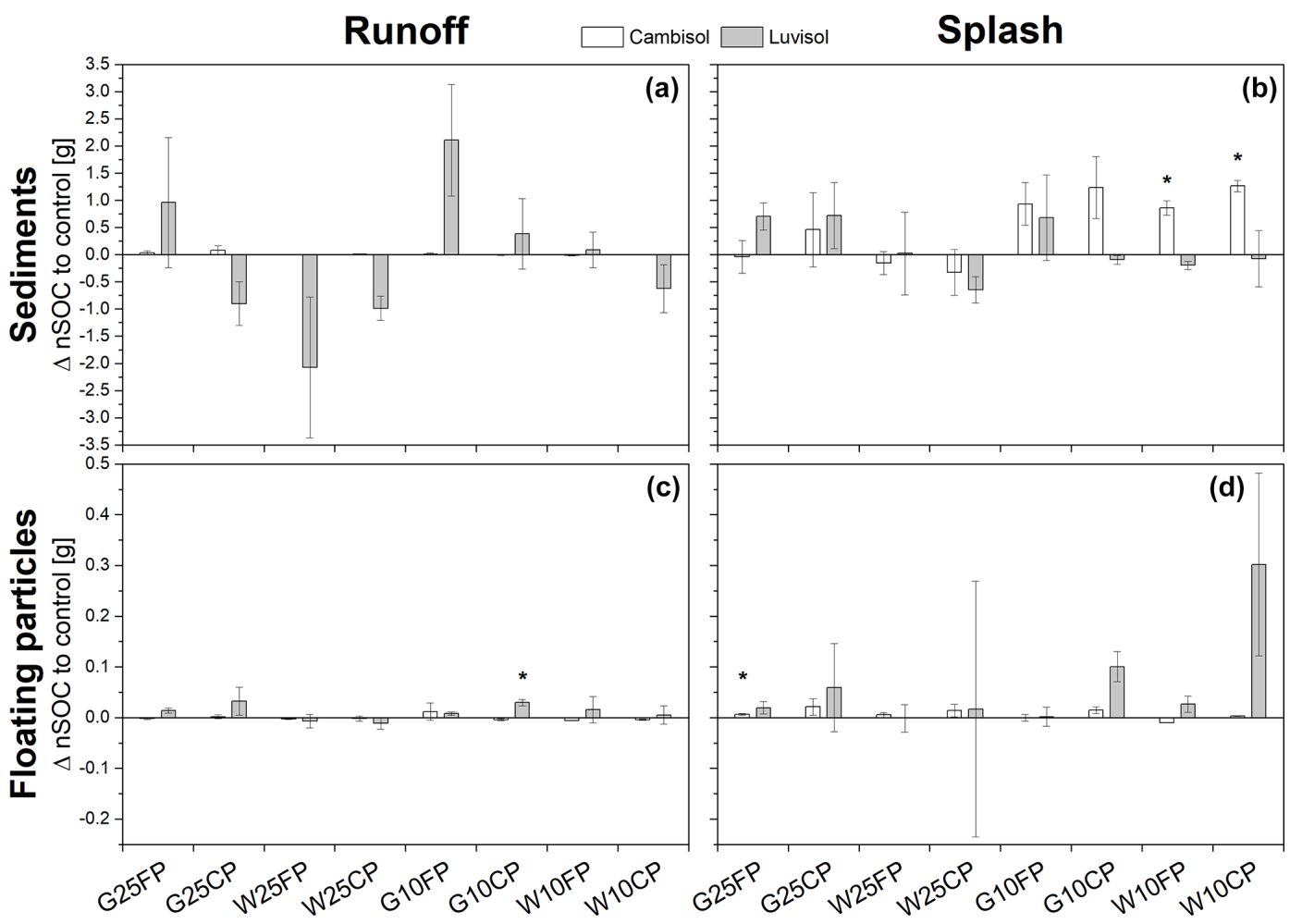

Figure 5. Differences in native SOC export ( $\triangle \mathrm{nSOC}$ to control in grams) between the PyC treatments $(\mathrm{nSOC}=\mathrm{TOC}-\mathrm{PyC})$ and the corresponding controls (nSOC $=$ TOC) in sediment transported by runoff (a), splash (b) and floating particles in runoff (c) and splash (d) after 30 min of rainfall (total 51.4 $\pm 1.4 \mathrm{~mm}$ ) (G: grass PyC; W: wood PyC; 25: $25^{\circ}$ slope; 10: $10^{\circ}$ slope; FP: fine PyC (<63 $\mu$ m); CP: coarse PyC $(63 \mu \mathrm{m}$ to $2 \mathrm{~mm}))$. Average values \pm 1 standard error $(n=3)$. Significant changes at $p<0.05$ are marked with an asterisk $\left({ }^{*}\right)$.

cated $\mathrm{PyC}$ in floating particles by splash was higher for coarser particles than finer ones (CP: $10.9 \pm 2.2 \%$ and FP: $0.03 \pm 0.01 \%)$, and this effect was significant for the Cambisol $(p=0.0003)$ and Luvisol ( $p<0.001$; Fig. 4 d).

\subsection{Changes of nSOC dynamics after application of PyC}

Our $\delta^{13} \mathrm{C}$ approach (using ${ }^{13} \mathrm{C}$-labeled $\mathrm{PyC}$ material) and the mass balance of TOC and PyC allowed us to estimate the effect of $\mathrm{PyC}$ application on the transport of native SOC (nSOC). We compared the transport of nSOC for control plots $(\mathrm{nSOC}=\mathrm{TOC})$ with plots where we added $\mathrm{PyC}$ $(\mathrm{nSOC}=\mathrm{TOC}-\mathrm{PyC})$. Changes in nSOC export through runoff after application of $\mathrm{PyC}$ were negligible for the Cambisol $\left(<0.5 \pm 0.1 \mathrm{~g} \mathrm{C} \mathrm{m}^{-2}\right)$ but important for the Luvisol (Fig. 5a). For the Luvisol, the changes varied from reduced export of the order of $8.4 \pm 5.2 \mathrm{~g} \mathrm{C} \mathrm{m}^{-2}$ (fine-grained wood $\mathrm{PyC}$ on $25^{\circ}$ slope; $p=0.25$ ) to higher export of the order of $8.4 \pm 4.0 \mathrm{~g} \mathrm{C} \mathrm{m}^{-2}$ (fine-grained grass $\mathrm{PyC}$ on $10^{\circ}$ slope; $p=0.16$ ) compared to controls (Fig. 5a). Changes of nSOC export through splash after application of $\mathrm{PyC}$ were important for the Cambisol at the $10^{\circ}$ slope but small for the Luvisol (Fig. 5b). For the $10^{\circ}$ Cambisol plots, we observed a higher export of nSOC after PyC application than for the control plots in the range of $3.6 \pm 1.6 \mathrm{~g} \mathrm{C} \mathrm{m}^{-2}$ (finegrained grass $\mathrm{PyC} ; p=0.13$ ) to $5.2 \pm 0.4 \mathrm{~g} \mathrm{C} \mathrm{m}^{-2}$ (finegrained wood $\mathrm{PyC})$. For the wood $\mathrm{PyC}$ application, higher exports were significant for fine $(p=0.01)$ and coarse $\mathrm{PyC}$ particles $(p=0.002)$. Changes in nSOC export as floating particles through runoff and splash after PyC application were small and highly variable (Fig. $5 \mathrm{c}-\mathrm{d}$ ).

\subsection{Distribution of $\mathrm{PyC}$ on the soil surface and in the soil}

\subsubsection{Upslope position}

For the upslope position (i.e., uppermost third where $\mathrm{PyC}$ was initially added), the distribution of $\mathrm{PyC}$ on the soil surface and in the soil after the rainfall simulation differed strongly for the two soil types (here reported as the fraction of $\mathrm{OC}$ derived from the $\mathrm{PyC}$ in percent (or PyC fraction)). We found more PyC at all three depths $(0-1,1-3$ and $3-10 \mathrm{~cm}$ ) in the Cambisol than the Luvisol (Fig. 6a-b and Table S2). For the surface layer $(0-1 \mathrm{~cm})$, the PyC fraction was $11.4 \pm 1.6 \%$ for the Cambisol and $7.5 \pm 0.9 \%$ for the Luvisol $(p=0.0009)$. At $1-3 \mathrm{~cm}$ depth, it was $4.8 \pm 0.5 \%$ for the Cambisol and $0.5 \pm 0.2 \%$ for the Luvisol $(p<0.001)$. At $3-10 \mathrm{~cm}$ depth, the difference was $2.0 \pm 0.3 \%$ for the Cam- 


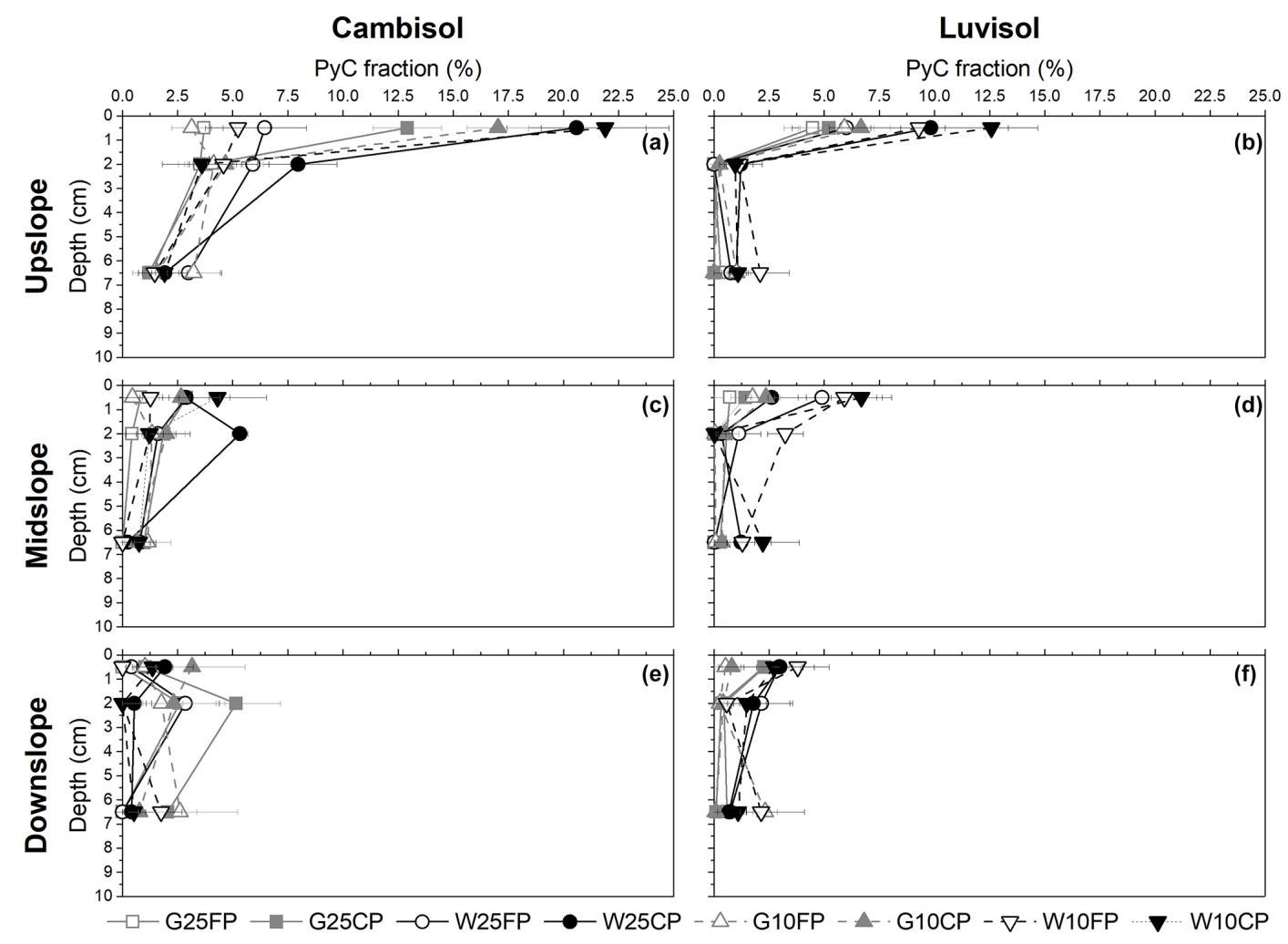

Figure 6. Distribution of $\mathrm{PyC}(\mathrm{PyC}$ fraction is the fraction of $\mathrm{OC}$ derived from the $\mathrm{PyC}$ in percent) in soil cores for the Cambisol (a, c, e) and Luvisol (b, d, f) along the $0.25 \mathrm{~m}^{2}$ plot (upslope: $\mathbf{a}-\mathbf{b}$; midslope; $\mathbf{c}-\mathbf{d}$ and downslope: e-f) and with depth $(0-1,1-3,3-10 \mathrm{~cm})$ for each treatment after $30 \mathrm{~min}$ rainfall (total: $51.4 \pm 1.4 \mathrm{~mm}$ ) (G: grass PyC; W: wood PyC; $25: 25^{\circ}$ slope; 10: $10^{\circ}$ slope; FP: fine PyC $(<63 \mu \mathrm{m})$; $\mathrm{CP}$ : coarse PyC (63 $\mu \mathrm{m}$ to $2 \mathrm{~mm}))$. Average values \pm 1 standard error $(n=3)$.

bisol and $0.8 \pm 0.2 \%$ for the Luvisol ( $p=0.007$ ). The visual assessment of the soil surface and vertical profile confirmed that more PyC remained on the surface or was washed in for the Cambisol than the Luvisol (Fig. 1b).

In addition to soil type, the distribution of $\mathrm{PyC}$ on the soil surface $(0-1 \mathrm{~cm})$ of the upper slope depended on PyC feedstock (Fig. 6a-b and Table S2). A larger PyC fraction remained on the surface when wood PyC $(11.5 \pm 1.5 \%)$ was applied than when grass PyC $(7.4 \pm 1.0 \%)$ was applied, and this effect was significant for the Cambisol $(p=0.005)$ and Luvisol ( $p=0.03$ ). Furthermore, significantly more PyC remained on the surface of the Cambisol when coarser PyC particles $(18.1 \pm 1.5 \%)$ were applied than finer ones $(4.6 \pm 0.7 \% ; p<0.001)$. The strong interaction of soil type and $\mathrm{PyC}$ particle size in our model suggests that coarse PyC remained on the soil surface of the Cambisol in the upslope position ( $p<0.001$; Fig. $6 \mathrm{a}$ and Table S2).

\subsubsection{Mid- and downslope}

In the midslope position, significant differences were only found for the Luvisol and were mainly related to PyC feedstock (Fig. 6c-d and Table S2). There was more PyC fraction on the surface $(0-1 \mathrm{~cm})$ of the Luvisol when wood PyC $(5.0 \pm 0.9 \%)$ was applied than for grass PyC $(1.6 \pm 0.3 \% ; p=0.002)$. This was also the case at $1-3 \mathrm{~cm}$ depth $(1.2 \pm 0.5 \%$ for wood PyC compared to $0.3 \pm 0.2 \%$ for grass $\mathrm{PyC} ; p=0.02$ ). In addition, there was significantly more $\mathrm{PyC}$ at $1-3 \mathrm{~cm}$ depth in the midslope position for the Cambisol than the Luvisol (PyC fraction: $1.9 \pm 0.4 \%$ for the Cambisol and $0.7 \pm 0.3 \%$ for the Luvisol; $p=0.002$ ). This difference was also seen for the downslope cores (Cambisol: $1.9 \pm 0.5 \%$ and Luvisol: $0.9 \pm 0.3 \%$ ) but was not significant $(p=0.11)$. The PyC fraction on the soil surface $(0-1 \mathrm{~cm})$ at the mid- and downslope positions was higher for the Luvisol than the Cambisol (Figs. 6c-f and 1b): $2.3 \pm 0.5 \%$ for the Cambisol and $3.3 \pm 0.6 \%$ for the Luvisol at the midslope position $(p=0.14)$. Downslope, it was $1.1 \pm 0.4 \%$ for the Cambisol and $2.3 \pm 0.5 \%$ for the Luvisol ( $p=0.058)$.

\section{Discussion}

\subsection{PyC redistribution by rainfall}

Our study provides evidence for a quick redistribution of $\mathrm{PyC}$ by intense rainfall. Between $0.18 \pm 0.05 \%$ and $36.0 \pm 4.6 \%$ of the initially added PyC was transported by runoff (both as sediment and floating particles), and between $10.3 \pm 1.7 \%$ 
and $25.3 \pm 3.7 \%$ of the initially added PyC was transported as splash (both as sediment and floating particles) during 30 min rainfall events $(51.4 \mathrm{~mm})$ on $0.25 \mathrm{~m}^{2}$ plots (Figs. 4 and 7). Therefore, our data confirm that the fate and mobility of PyC on short timescales depends to a great extent on its initial interaction with water (Masiello and Berhe, 2020). The portions of PyC relocated by runoff ( $\%$ of total added PyC; Fig. 4a and c) are of the same order of magnitude as observed for post-fire, plot-scale erosion field studies. Rumpel et al. (2009) reported that between $7 \%$ and $29 \%$ of initially applied PyC was transported by runoff. Cotrufo et al. (2016) found that $11 \%$ of PyC present in the organic layer was exported during the first year after a fire, and Major et al. (2010) estimated that around $20 \%$ to $53 \%$ of applied PyC must be relocated by erosion. In addition, Rumpel et al. (2009) reported PyC erosion by splash of $31.2 \pm 21.3 \%$, and our values of PyC recovery are well within this range (Fig. $4 \mathrm{~b}$ and d). However, it has to be mentioned that other studies have also reported limited transport of PyC $(<2 \%$ of TOC in runoff) after 62 years after a fire (Güereña et al., 2015).

Initial rainfall determines not only the redistribution of $\mathrm{PyC}$ on the surface, but also the quantity of PyC that moves into the soil (Masiello and Berhe, 2020). We recovered part of the initially added PyC (PyC fraction) at $1-3$ and $3-10 \mathrm{~cm}$ depth at the upslope position where it was initially applied, especially for the Cambisol (6.8\% (Cambisol) and 1.3\% (Luvisol); Fig. 6a-b). This shows that $\mathrm{PyC}$ moved through the soil profile within 30 min under unsaturated conditions. Due to the small amounts of PyC compared to the total mass of soil in our plots (on average $26.0 \pm 0.2 \mathrm{~kg}$ soil per plot), we could only calculate the fraction of OC that is $\mathrm{PyC}$ (PyC fraction) in the soil column, but no PyC recovery (\% of total added PyC). This limits the comparison with literature values. We chose larger quantities of soil (larger plot size) to eliminate possible boundary effects of the plots on PyC redistribution. However, in accordance with our findings, vertical movement of ${ }^{13} \mathrm{C}$-labeled wood PyC (3\% to $4 \%$ of applied PyC) up to $10-15 \mathrm{~cm}$ depth in soil cylinders after 10 months under field conditions has been reported for one of the sites from which we took the soil for our plots (Cambisol at the Lägern site) (Singh et al., 2014). In other studies conducted on soil plots or soil microcosms (between 8 and $20 \mathrm{~cm}$ long and $10 \mathrm{~cm}$ in diameter) in the field or in the laboratory, relocated quantities by vertical movement up to $10 \mathrm{~cm}$ depth after $1-2$ years varied between $<1 \%$ and $2.3 \%$ of initially applied PyC (in particulate or dissolved form) (Hilscher and Knicker, 2011; Maestrini et al., 2014; Major et al., 2010). Even larger amounts (23\% to $46 \%$ of initially applied PyC) have been reported for plot-scale rainfall simulations in the tropics, but this vertical transport was limited to $1 \mathrm{~cm}$ depth (Rumpel et al., 2009).

\subsection{Effect of PyC application on $\mathrm{nSOC}$ redistribution}

By using ${ }^{13} \mathrm{C}$-labeled PyC, we were able to show for the first time (to our knowledge) that the application of $\mathrm{PyC}$ to the soil surface and its subsequent redistribution affect the fate and redistribution of native SOC (nSOC). The changes in nSOC export by runoff and splash after application of PyC were of the same order of magnitude as the PyC flux after the rainfall event but highly variable, and the underlying processes are not fully clear and need further investigation (Fig. 5). These changes could be related to the sorption and stabilization of nSOC to PyC surfaces (Jiang et al., 2019; Singh et al., 2014), or the strong affinity of PyC to sorb to mineral surfaces, which can promote the mobilization of less effectively adsorbed nSOC through desorption (Jiang et al., 2016). However, it seems unlikely that these processes take place within minutes. Another possible explanation could be that PyC particles on the soil surface increase the soil hydrophobicity and lead to a longer contact time between water and nSOC, which may promote its export. However, it is still surprising that such a process would result in such a large export flux of nSOC. More specific experiments are needed to fully understand these processes.

\subsection{Key drivers of soil, TOC and $\mathrm{PyC}$ redistribution}

\subsubsection{Soil type}

Soil type was the main explanatory variable that influenced soil, TOC and PyC redistribution by surface runoff (Figs. 2a, $3 \mathrm{a}$ and $4 \mathrm{a})$. This can be related to the soils' physical and hydrological properties. The higher runoff ( 7 times higher for the Luvisol than the Cambisol; Table 1) and reduced infiltration rates (Fig. S3) for the Luvisol, despite its sandy silty texture, can be explained by its lower aggregate stability (Table 1). Runoff ratios between $13.2 \pm 0.8 \%$ (Cambisol) and $88.5 \pm 2.3 \%$ (Luvisol) for a $102.8 \mathrm{~mm} \mathrm{~h}^{-1}$ rainfall on $0.25 \mathrm{~m}^{2}$ plots are comparable to those reported from rainfall simulation experiments $\left(80-85 \mathrm{~mm} \mathrm{~h}^{-1}\right.$ rainfall on $0.28 \mathrm{~m}^{2}$ plots) in Portugal, with runoff coefficients of $7 \%$ to $55 \%$ on Leptosols and Umbrisols (Malvar et al., 2013). Difference in runoff amount for the two soil types was only by a factor of 7 but the erosion differed by a factor of 150 (Fig. 2a), which indicates that the higher erosion on the Luvisol is a result of the Luvisols' physical instability and susceptibility to erosion (i.e., the low aggregate stability and SOC content) and not only a result of the higher water flow (Koiter et al., 2017). Surface sealing is generally stronger for soils with a coarser soil texture and lower organic matter content (Armenise et al., 2018). In contrast, clay-rich soils with a high physical stability (i.e., high aggregate stability) and higher TOC content are less prone to erosion, as they do not lead to rapid surface sealing and therefore slow down runoff generation and erosion (Berhe and Kleber, 2013; de Nijs and Cammeraat, 2020; Thomaz, 2018). The eroded quan- 
tities of soil $\left(5.2 \pm 0.8 \mathrm{~g} \mathrm{~m}^{2}\right)$ and TOC $\left(0.32 \pm 0.04 \mathrm{~g} \mathrm{C} \mathrm{m}^{2}\right)$ for the Cambisol are in the same range as for a clay-rich Alfisol $\left(28 \pm 76\right.$ to $\left.60 \pm 249 \mathrm{~g} \mathrm{~m}^{-2}\right)$ and TOC $(0.9 \pm 9.8$ to $2.2 \pm 16.2 \mathrm{~g} \mathrm{C} \mathrm{m}^{2}$ ) on $1 \mathrm{~m}^{2}$ field plots (Chaplot et al., 2005). For the Luvisol, eroded quantities of soil $\left(786.8 \pm 57.2 \mathrm{~g} \mathrm{~m}^{2}\right)$ and TOC $\left(29.2 \pm 2.0 \mathrm{~g} \mathrm{C} \mathrm{m}^{2}\right)$ are of the same order of magnitude as for a field study conducted on loess-derived Luvisols in Belgium (using $45 \mathrm{~mm} \mathrm{~h}^{-1}$ on $0.72 \mathrm{~m}^{2}$ plots), with a soil loss of $330.2 \pm 525.6 \mathrm{~g} \mathrm{~m}^{-2} \mathrm{~h}^{-1}$ and a SOC loss of $4.8 \pm 5.5 \mathrm{~g} \mathrm{C} \mathrm{m}^{-2} \mathrm{~h}^{-1}$ (Wang et al., 2010). Also Schindler Wildhaber et al. (2012) found clear differences in soil losses by runoff: $894 \pm 282 \mathrm{~g} \mathrm{~m}^{-2}$ for a silty soil with low SOC content $\left(1.7 \pm 0.9 \%\right.$ OC) compared to $191 \pm 54 \mathrm{~g} \mathrm{~m}^{-2}$ for a clay-rich soil with high SOC content $(5.2 \pm 2.3 \%$ OC) under $60 \mathrm{~mm} \mathrm{~h}^{-1}$ for $2 \mathrm{~h}$ in field and laboratory studies. They related the differences in the losses to variable soil structural stabilities and therefore susceptibility to erosion. The higher values of soil and SOC relocation in our study could partially be explained by the higher rainfall intensity $\left(102.8 \mathrm{~mm} \mathrm{~h}^{-1}\right)$ since soil erosion is significantly correlated to rainfall intensity (Chaplot and Le Bissonnais, 2003).

Soil type is also a main explanatory variable for $\mathrm{PyC}$ relocation by runoff (Figs. 4a and 7). The higher redistribution of $\mathrm{PyC}$ on the Luvisol than the Cambisol can be explained by the same processes as soil and TOC transport (i.e., rapid surface sealing, higher erodibility and higher runoff ratio (and thus higher sediment transport) for the Luvisol than for the Cambisol). The high runoff and transport rates on the Luvisol promoted the redistribution of the low-density PyC particles on the soil surface (Abney and Berhe, 2018; Bird et al., 2015; Rumpel et al., 2006). Surface sealing can be increased when aggregates are broken down and PyC (ash and char) is washed into the soil and fills flow pathways in mechanically weaker soils (Certini, 2005; Onda et al., 2008). In contrast, the physical and hydrological properties of the Cambisol changed very little during the rain event, i.e., only $5.2 \pm 0.8 \mathrm{~g}$ sediment per square meter was recovered after $30 \mathrm{~min}$ (indicating reduced aggregate breakdown and soil loss), and soil moisture was still increasing at the end of the rainfall simulation (indicating continuous infiltration (Fig. S3)). This caused the 7 times lower runoff and 300 times smaller PyC relocation by runoff on the Cambisol than the Luvisol.

Redistribution of soil, TOC and $\mathrm{PyC}$ by splash was higher for the Luvisol, but differences with the Cambisol were much smaller than for the transport of soil, TOC and $\mathrm{PyC}$ by the runoff (Figs. 2b, $3 \mathrm{~b}$ and $4 \mathrm{~b}$ ). The measured quantities of eroded soil by splash $\left(262.0 \pm 14.4 \mathrm{~g} \mathrm{~m}^{-2}\right.$ (Cambisol) and $382.0 \pm 18.0 \mathrm{~g} \mathrm{~m}^{-2}$ (Luvisol)) are in agreement with reported values of splashed soil for a clay loam $\left(290 \pm 10 \mathrm{~g} \mathrm{~m}^{-2}\right)$ and for a silt loam $\left(550 \pm 10 \mathrm{~g} \mathrm{~m}^{-2}\right)$ or sand $\left(730 \pm 20 \mathrm{~g} \mathrm{~m}^{-2}\right)$ under $30 \mathrm{~mm} \mathrm{~h}^{-1}$ rainfall (Legout et al., 2005). Splash erosion, or the impact of raindrops on soil particles, is often considered the first and dominant process of soil detachment and transport over small distances and depends on rainfall characteristics and soil surface prop- erties (Malam Issa et al., 2006; de Nijs and Cammeraat, 2020). The amount of splashed soil by raindrops generally increases with decreasing physical stability of soil (i.e., faster aggregate breakdown) and can therefore explain the larger amounts of splashed sediment for the Luvisol than the Cambisol in our study (see Legout et al., 2005). However, the measured quantities of eroded TOC by splash for the Cambisol $\left(11.6 \pm 0.8 \mathrm{~g} \mathrm{C} \mathrm{m}^{-2}\right)$ and Luvisol $\left(13.2 \pm 0.8 \mathrm{~g} \mathrm{C} \mathrm{m}^{-2}\right)$ were much closer than the splashed sediments, indicating that erosion by splash preferentially moves lighter particles (i.e., high SOC content) (Beguería et al., 2015). In a field rainfall experiment in Spain, Beguería et al. (2015) found an empirical coefficient of $13 \mathrm{mg}$ SOC relocated per gram of splashed sediment, with the highest SOC mobilization by splash for a sandy loam Gypsisol and the lowest for a silty Cambisol. The coefficients for our study are of the same order of magnitude: $44.3 \mathrm{mg} \mathrm{TOC} \mathrm{g}^{-1}$ splashed sediment for the Cambisol and $34.6 \mathrm{mg} \mathrm{TOC}^{-1}$ splashed sediment for the Luvisol. The higher coefficient for the Cambisol may be caused by the significantly higher SOC stock in the first $10 \mathrm{~cm}$ of soil $\left(36.0 \pm 4.0 \mathrm{Mg} \mathrm{ha}^{-1}\right.$ for the Cambisol vs. $23.4 \pm 0.2 \mathrm{Mg} \mathrm{ha}^{-1}$ for the Luvisol; Table 1).

Soil type also influenced $\mathrm{PyC}$ translocation by splash (Figs. $4 \mathrm{~b}$ and 7). The smaller difference between the two soil types indicates that PyC erosion by splash depends much less on soil type than it did for runoff. Splash preferentially moves lighter particles (Beguería et al., 2015). Along the argumentation above for TOC, this effect can be related to the fact that $\mathrm{PyC}$ was available on the soil surface of both soils and the physical properties of $\mathrm{PyC}$, such as the low density.

Finally, soil type was the main explanatory variable for vertical movement of $\mathrm{PyC}$ through the $10 \mathrm{~cm}$ soil column (Fig. 6). We found more $\mathrm{PyC}$ at $3-10 \mathrm{~cm}$ depth in the Cambisol than the Luvisol at the upslope position where $\mathrm{PyC}$ was initially added, as well as in the subsurface along the slope gradient. The higher vertical and subsurface mobility of $\mathrm{PyC}$ in the Cambisol compared to the Luvisol under unsaturated conditions (and excluding leaching of soluble parts) can be explained by higher infiltration rates for the Cambisol with high aggregate stability (Table 1 and Fig. S3). Therefore, more PyC was physically translocated (i.e., as particulate $\mathrm{PyC}$ or clay-sized $\mathrm{PyC}$ ) with the percolating water running through larger soil pores (Hilscher and Knicker, 2011; Rumpel et al., 2015; Soucémarianadin et al., 2019). This vertical transport was limited in the Luvisol due to quicker surface sealing. The vertical movement of PyC depends largely on PyC size and solubility, but also on soil properties such as texture, aggregation, porosity and the infiltration rate (Abney et al., 2017), which in our study were more favorable in the Cambisol.

\subsubsection{PyC characteristics}

PyC characteristics (feedstock and particle size) was the second most important explanatory variable affecting PyC re- 


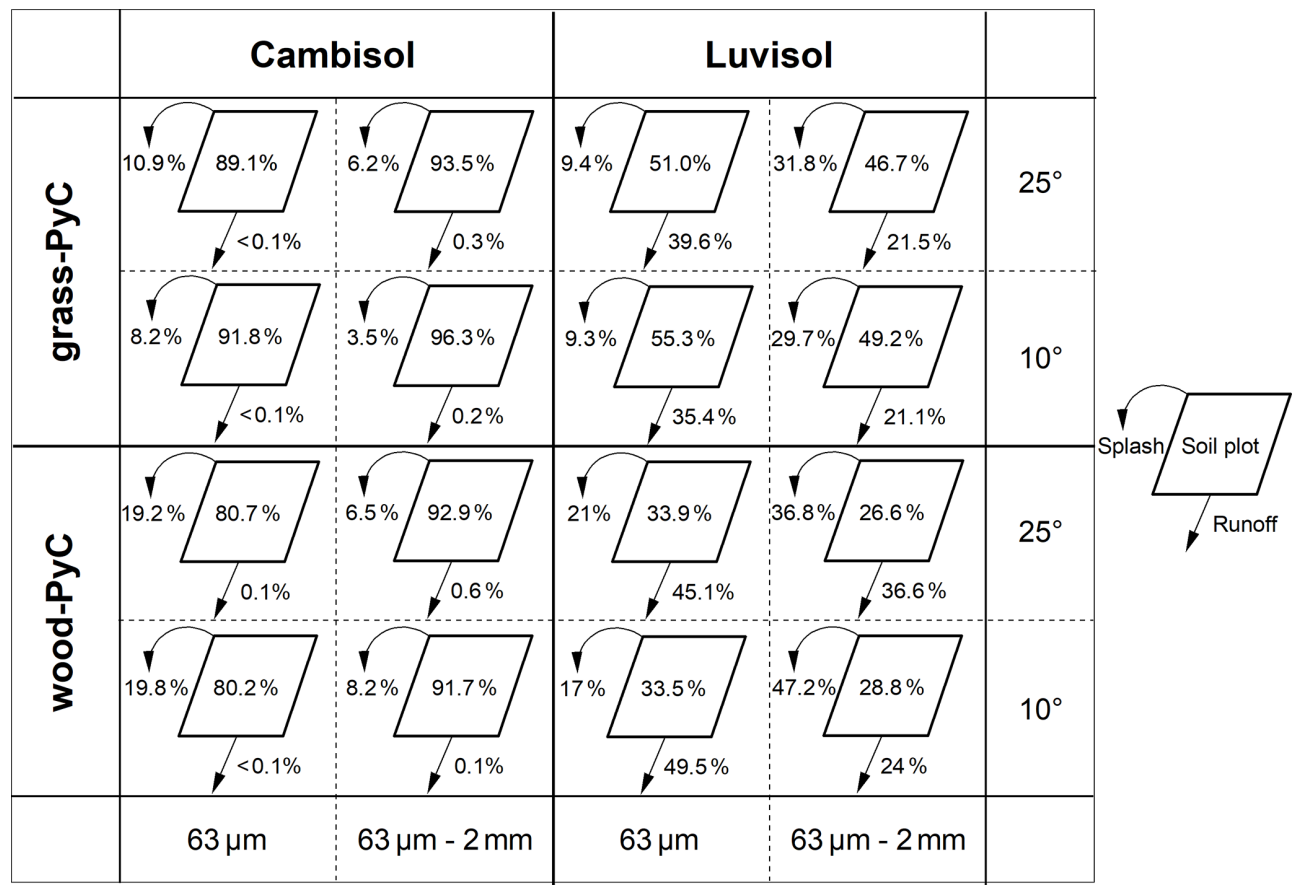

Figure 7. Redistribution of $\mathrm{PyC}(\%)$ through runoff and splash erosion and within the soil plots for all combinations of studied drivers (soil texture (Cambisol vs. Luvisol), slope angle $\left(25^{\circ}\right.$ vs. $\left.10^{\circ}\right)$, PyC feedstock (grass vs. wood) and particle size $(63 \mu \mathrm{m}$ vs. $63 \mu \mathrm{m}-2 \mathrm{~mm})$ ). Values represent averages per treatment $(n=3)$.

distribution (Fig. 7). For PyC feedstock, however, we found contradictory results, in particular for wood PyC. On the one hand, there was more wood PyC transport by runoff and splash (sediment + floating particles) than grass PyC transport for both soils (\% of total added PyC: $43.4 \pm 6.6 \%$ for wood PyC and $28.4 \pm 4.6 \%$ for grass PyC; Fig. 4). On the other hand, we also found more wood $\mathrm{PyC}$ than grass $\mathrm{PyC}$ on the soil surface $(0-1 \mathrm{~cm})$ in the upslope position where $\mathrm{PyC}$ was applied for both soils (fraction of OC derived from the $\mathrm{PyC}$ in percent (or PyC fraction): $11.5 \pm 1.5 \%$ for wood $\mathrm{PyC}$ and $7.4 \pm 1.0 \%$ for grass PyC; Fig. 6a-b), indicating that wood $\mathrm{PyC}$ either remained where initially applied or moved outside the $0.25 \mathrm{~m}^{2}$ plot, while grass PyC was redistributed more within the plot. The latter observation is in line with the general concept that grass-derived $\mathrm{PyC}$ has greater mobility than wood-derived $\mathrm{PyC}$, which remains closer to its site of formation and initial deposition (Saiz et al., 2018). The higher mobility of grass $\mathrm{PyC}$ could be explained by its higher fragmentation potential due to the lack of strong physical structures of grass feedstock compared to wood feedstock (Pignatello et al., 2015; Singh et al., 2012). Wood feedstock is generally richer in lignin, and the resulting wood PyC is more crystalline and aromatic (Keiluweit et al., 2010; Singh et al., 2012), which was also the case for our PyC (Fig. S1). These differences can explain the higher retention of wood PyC compared to grass PyC on the soil surface at the upslope position of the plots, but not the greater relocation of wood PyC than grass PyC by runoff and splash. We assume that this is caused by the greater fragmentation of grass $\mathrm{PyC}$ into smaller particles by raindrop impact. These smaller particles are more easily distributed in the soil, which makes them more difficult to detect based on $\delta^{13} \mathrm{C}$ and the proportion of PyC (few grams) to soil (several kilograms) (McCorkle et al., 2016; Pignatello et al., 2015). Overall, we found much more of the applied wood $\mathrm{PyC}$ than the grass $\mathrm{PyC}$, for both PyC recoveries (\% of total added PyC: $43.4 \pm 6.6 \%$ for wood $\mathrm{PyC}$ and $28.4 \pm 4.6 \%$ for grass PyC; Fig. 4) and $\mathrm{PyC}$ fraction (fraction of $\mathrm{OC}$ derived from the $\mathrm{PyC}$ in percent: $26.9 \pm 4.9 \%$ for wood $\mathrm{PyC}$ and $17.7 \pm 3.8 \%$ for grass $\mathrm{PyC}$; Fig. 6), which supports this assumption. Spokas et al. (2014) further observed the same or higher levels of fragmentation for wood-derived feedstocks (lignin-rich) compared to grassderived feedstocks (cellulose-rich), depending on the experimental conditions applied. Our different findings ultimately indicate that both the fragmentation potential and the mobility of PyC do not only depend on the feedstock material (grass versus wood) but also other factors such as surface area, porosity, induced mechanical stresses, etc. (Crawford and Belcher, 2014; Singh et al., 2012; Spokas et al., 2014).

For the runoff and splashed sediment (without floating particles), the mobility of fine $\mathrm{PyC}$ particles was larger than for the coarse particles (Fig. 4a-b). This finding is in line with the greater retention of coarse PyC particles on the soil surface $(0-1 \mathrm{~cm})$ in the upper part of the plot where PyC was added, especially for the Cambisol (Fig. 6a-b). Particle size can be a key driver of long-distance transport of PyC. It is 
generally assumed that the surface transport potential and efficiency is greater for finer $\mathrm{PyC}$ particles and they are therefore transported over longer distances (off-site export) than coarser particles that remain closer to the site of formation (Abiven and Santín, 2019; Masiello, 2004; Saiz et al., 2018; Tinner et al., 2006). Finer PyC particles also remain in suspension for a longer period of time as they settle from the mixture more slowly (according to Fick's law) (Rumpel et al., 2015). Since the particle size determines PyC susceptibility to erosive transport, fragmentation after initial deposition (and during transport) can increase the transport potential of PyC particles. Higher fragmentation of grass $\mathrm{PyC}$ into smaller particles could ultimately lead to higher mobility (Pignatello et al., 2015; Rumpel et al., 2015). Only for the separated floating particles eroded by runoff and splash (Fig. 4c-d) were the coarse PyC particles more prevalent. The larger quantities of coarse PyC in the floating particles of runoff and splash are caused by the higher floating potential of coarser PyC, likely due to its low density and high porosity (Rumpel et al., 2015).

\subsubsection{Slope}

Slope angle had a minor effect on the mobilized quantities of soil, SOC and PyC and was only significant for the Luvisol, where a slope of $25^{\circ}$ resulted in increased soil and TOC, but not PyC erosion by runoff (Figs. 2-4). As slope was only relevant for the Luvisol and only for particles transported by runoff, it could be related to the greater runoff ratio and therefore surface transport for the Luvisol under a $25^{\circ}$ slope. Several studies have confirmed the limited effect of slope on PyC redistribution (Boot et al., 2015; Cotrufo et al., 2016; Galanter et al., 2018), but it is important to note that slope angle may be more important on larger plots or along hillslopes where slope angle can be assessed together with slope length and aspect (Abney and Berhe, 2018; Shakesby et al., 2015). These two topographic features could not be assessed in our plot-scale study.

\subsection{Consequences for understanding PyC redistribution in the landscape after fire}

Our findings regarding the factors that affect PyC relocation during simulated rainfall events advance our understanding of $\mathrm{PyC}$ redistribution in the landscape. We show that PyC was highly mobile and quickly transported and relocated on $0.25 \mathrm{~m}^{2}$ plots during $30 \mathrm{~min}$ of intense rainfall. Our experimental study was done under controlled conditions, which partially limits a direct comparison of our data to natural hillslopes. To fully understand PyC redistribution and deposition in the landscape after a fire, it is therefore of great importance to assess initial post-fire rainfall events and to track PyC relocation by erosion at the hillslope and catchment scales (Cotrufo et al., 2016; Masiello and Berhe, 2020). In particular, the plots used in this study are much shorter than real hillslopes and therefore do not account for longdistance transport (Rumpel et al., 2006). For longer hillslopes, slope steepness, length and aspect, and post-fire surface roughness but also micro-topographic features such as depressions or the formation of rills and gullies affect the effective infiltration rates and transport capacity of overland flow, and thus runoff erosion and $\mathrm{PyC}$ redistribution. With increasing hillslope steepness and decreasing surface roughness (due to removal of ground cover after a fire), surface runoff and PyC transport will likely increase; with increasing hillslope length, the transport capacity of overland flow generally declines, which increases the chances that $\mathrm{PyC}$ is deposited along the slope or in lower-lying areas of catchments and can ultimately enter the soil (Abney and Berhe, 2018; Masiello and Berhe, 2020). In this regard, it has to be noted that not only runoff erosion will likely change on longer hillslopes, but also the interaction of runoff and splash erosion. With our methodological approach, we could not fully separate these two processes, and parts of eroded material by splash accounted for runoff erosion since they occurred on the soil plots themselves in the direction of the slope, which favors its final export by runoff.

In addition, the results will be different for real post-fire landscapes because of the heterogeneity in ground cover and soil hydrological and physical properties of fire-affected (burned) soils. Fire-affected soils are affected by changes in i.e., vegetation cover, hydrophobicity, water repellence, infiltration or aggregate breakdown (Abney and Berhe, 2018; Moody et al., 2013; Shakesby, 2011). The fire regime (severity, intensity and frequency) will determine the fuel consumption, as well as PyC production and characteristics (Bowman et al., 2009; Santín et al., 2015). In our experiment, we used unburnt soil without ground cover except for the added PyC. Fires remove substantial proportions of ground cover (up to $90 \%$ ), but after an actual fire the soil surface may be covered with debris, ash, charcoal or partially burned plant material, which will lead to a patchy ground cover (Johansen et al., 2001; Pierson et al., 2013; Shakesby and Doerr, 2006). In our study, both the soils (very hydrophilic) and PyC materials (extremely hydrophobic) were similarly water repellent (Tables 1-2). On real fire-affected hillslopes, burnt soils will likely be more water repellent, leading to more runoff and likely more transport of particles and PyC (DeBano, 2000). Fires can also change the water-holding capacity of soils and soil chemistry (Fonseca et al., 2017; Moragues-Saitua et al., 2017; Robichaud et al., 2016). However, we did not change the soils' physical structure (i.e., aggregation or porosity) prior to rainfall experiments, except that we slightly smoothened the surface. Burned soils may strongly be affected by changes in aggregation, porosity and therefore infiltration capacity due to heat-induced aggregate breakdown, volatilization or charring of organic matter, or inwash of particles, such as ash or PyC, resulting in more pore clogging and surface sealing than in our experiment (Certini, 2005; Jian et al., 2018). However, limited clogging through 
washin of ash or PyC has also been found (Stoof et al., 2016). Even though we did not account for these changes in fireaffected soils, our results of $\mathrm{PyC}$ redistribution are relatively comparable with plot-scale studies using burnt soils in the field (Rumpel et al., 2009).

Precipitation also has a great influence on post-fire erosion dynamics but is highly variable in nature and depends on local to regional climatic conditions. Although rainfall simulation experiments on plots are essential to understand individual processes during single erosion events due to high level of control and comparability, they are limited in spatial and temporal extent (Clarke and Walsh, 2007; Doetterl et al., 2016; Iserloh et al., 2012). PyC redistribution after rainfall will not be uniform in time and space, and it is therefore important to use multiple successive events in future studies to take this temporal and spatial evolution into account (Moody et al., 2013). Using longer rainfall durations or successive rainfall events would likely have resulted in parts of the remaining $\mathrm{PyC}$ on the soil surface to be further relocated by runoff and splash, but probably to a much lesser extent. Longer rainfall events could facilitate redistribution of $\mathrm{PyC}$ that had already entered the soil column after $30 \mathrm{~min}$. A lower rainfall intensity would likely have led to less overland flow and reduced transport by runoff, but possibly still substantial PyC redistribution due to preferential relocation of low-density particles like PyC. An even higher rainfall intensity would likely have led to more overland flow and increased sediment and PyC transport (Moody et al., 2013; Rumpel et al., 2015). Higher rainfall intensities or longer durations could likely further facilitate breakdown of PyC particles due to the impact of the raindrops, subsequently increasing its mobility.

Despite the limitations of these experimental settings, controlled conditions and multi-factorial experiments are crucial for our understanding of key drivers of PyC redistribution. The data and findings of this study give directions for larger-scale field studies and help generalization of model parameters. In particular, our results clearly show that soil type affects the mobility of PyC (Fig. 7). PyC export is less for a fine-textured well-aggregated soil than for silty soil with poorer aggregate stability. This result is in line with the notion that soil properties, together with key hydrological drivers, determine the spatial variability of PyC in soils at the landscape scale (Rumpel et al., 2009; Soucémarianadin et al., 2019). Our findings indicate that PyC redistribution depends on the feedstock from which it was derived (Fig. 7). Both wood and grass PyC can be highly mobile, depending, at least partially, on its particle size. PyC relocation may be greater for grassland-dominated than tree-dominated catchments because grass $\mathrm{PyC}$ is smaller and more susceptible to fragmentation, therefore potentially breaking apart into even smaller pieces that are more mobile (Pignatello et al., 2015; Saiz et al., 2018). Consequently, vegetation cover determines the feedstock for PyC production, which in turn will likely govern the size, stability and therefore mobility of PyC (Saiz et al., 2018). This needs to be taken into account for field in- vestigations and for modeling of $\mathrm{PyC}$ erosion at the hillslope or catchment scale. In addition, our results suggest that the presence and redistribution of $\mathrm{PyC}$ in the landscape can affect soil organic matter mobilization. We showed that $\mathrm{nSOC}$ export changes in the presence of $\mathrm{PyC}$, but the processes that cause these changes could not be assessed and need further study.

\section{Conclusions}

The rainfall simulation experiment on $0.25 \mathrm{~m}^{2}$ soil plots presented here shows that large quantities of PyC can be redistributed during a short period of time. Between $3.7 \pm 1.0 \%$ and $73.4 \pm 3.8 \%$ of the initially added PyC was redistributed by runoff and splash during a $30 \mathrm{~min}$ high intensity rainfall event. Soil texture, slope angle, PyC feedstock and particle size affect the mobilization of PyC to a different extent. Soil type substantially influences the redistribution of $\mathrm{PyC}$ at the plot scale, probably due to differences in texture, aggregate stability, and SOC contents. For the studied Cambisol, only a little PyC was moved with runoff or splash, and significantly more $\mathrm{PyC}$ remained on the plot where it was initially applied or moved vertically into the soil. For the Luvisol, large quantities of PyC were moved with runoff and splash, but only a little PyC moved vertically into the soil column. Furthermore, the erosional behavior of wood and grass PyC differed, suggesting that this must be taken into account when determining post-fire erosion budgets for catchments under different vegetation. While more wood $\mathrm{PyC}$ was mobilized by runoff and splash than grass $\mathrm{PyC}$, also more wood $\mathrm{PyC}$ was retained on the surface where it was initially applied. Alongside PyC feedstock, particle size also influences the mobility and off-site transport of PyC. Relocation of PyC may be greater for grass-dominated ecosystems because grass $\mathrm{PyC}$ is initially smaller and also more susceptible to fragmentation; the finer PyC, the more susceptible to redistribution. Slope angle had only a minor effect on PyC relocation at the plot scale but must be taken into account for larger scales, such as hillslopes or catchments. Finally, the presence and relocation of PyC affected the mobilization and export of native SOC.

The identification of the relative importance of these individual drivers of $\mathrm{PyC}$ redistribution will help to improve the design of more time- and cost-intensive field studies. Our simulation experiments can also provide crucial inputs to simulate the fate of $\mathrm{PyC}$ in landscape or Earth system models. However, further research is needed to understand the importance of key drivers of $\mathrm{PyC}$ redistribution at larger scales, such as hillslopes or catchments, in order to explain the spatial heterogeneity of SOC and PyC stocks in the landscape.

Data availability. The data related to this article are available at https://doi.org/10.5281/zenodo.4422514 (Bellè and Abiven, 2021). 
Supplement. The supplement related to this article is available online at: https://doi.org/10.5194/bg-18-1105-2021-supplement.

Author contributions. SA acquired the funding. SB and SA conceptualized the study. SB conducted the experiment, analyzed and visualized the data, and wrote the manuscript, and all authors commented on the manuscript.

Competing interests. The authors declare that they have no conflict of interest.

Acknowledgements. The authors acknowledge the support and ability to use the facilities at the Swiss Federal Institute for Forest, Snow and Landscape Research (WSL), especially Manfred Staehli and Werner Gerber. We further thank Thomas Keller (University of Zurich) for technical assistance.

Financial support. This research has been supported by the Swiss National Science Foundation (grant no. 200021_178768).

Review statement. This paper was edited by Yakov Kuzyakov and reviewed by Diana Vieira and one anonymous referee.

\section{References}

Abd Elbasit, M. A. M., Yasuda, H., Salmi, A., and Anyoji, H.: Characterization of rainfall generated by dripper-type rainfall simulator using piezoelectric transducers and its impact on splash soil erosion, Earth Surf. Processes, 35, 466-475, https://doi.org/10.1002/esp.1935, 2010.

Abiven, S. and Santín, C.: Editorial: From Fires to Oceans: Dynamics of Fire-Derived Organic Matter in Terrestrial and Aquatic Ecosystems, Front. Earth Sci., 7, 31, https://doi.org/10.3389/feart.2019.00031, 2019.

Abney, R. B. and Berhe, A. A.: Pyrogenic Carbon Erosion: Implications for Stock and Persistence of Pyrogenic Carbon in Soil, Front. Earth Sci., 6, 26, https://doi.org/10.3389/feart.2018.00026, 2018.

Abney, R. B., Sanderman, J., Johnson, D., Fogel, M. L., and Berhe, A. A.: Post-wildfire Erosion in Mountainous Terrain Leads to Rapid and Major Redistribution of Soil Organic Carbon, Front. Earth Sci., 5, 99, https://doi.org/10.3389/feart.2017.00099, 2017.

Abney, R. B., Kuhn, T. J., Chow, A., Hockaday, W., Fogel, M. L., and Berhe, A. A.: Pyrogenic carbon erosion after the Rim Fire, Yosemite National Park: the role of burn severity and slope, J. Geophys. Res.-Biogeo., 124, 432-449, https://doi.org/10.1029/2018jg004787, 2019a.

Abney, R. B., Jin, L., and Berhe, A. A.: Soil properties and combustion temperature: Controls on the decomposition rate of pyrogenic organic matter, Catena, 182, 104127, https://doi.org/10.1016/j.catena.2019.104127, 2019b.
Abudi, I., Carmi, G., and Berliner, P.: Rainfall simulator for field runoff studies, J. Hydrol., 454-455, 76-81, https://doi.org/10.1016/j.jhydrol.2012.05.056, 2012.

Aksoy, H., Unal, N. E., Cokgor, S., Gedikli, A., Yoon, J., Koca, K., Inci, S. B., and Eris, E.: A rainfall simulator for laboratory-scale assessment of rainfall-runoff-sediment transport processes over a two-dimensional flume, Catena, 98, 63-72, https://doi.org/10.1016/j.catena.2012.06.009, 2012.

Archibald, S., Lehmann, C. E. R., Gómez-Dans, J. L., and Bradstock, R. A.: Defining pyromes and global syndromes of fire regimes, P. Natl. Acad. Sci. USA, 110, 6442-6447, https://doi.org/10.1073/pnas.1211466110, 2013.

Armenise, E., Simmons, R. W., Ahn, S., Garbout, A., Doerr, S. H., Mooney, S. J., Sturrock, C. J., and Ritz, K.: Soil seal development under simulated rainfall: Structural, physical and hydrological dynamics, J. Hydrol., 556, 211-219, https://doi.org/10.1016/j.jhydrol.2017.10.073, 2018.

Beguería, S., Angulo-Martínez, M., Gaspar, L., and Navas, A.: Detachment of soil organic carbon by rainfall splash: Experimental assessment on three agricultural soils of Spain, Geoderma, 245246, 21-30, https://doi.org/10.1016/j.geoderma.2015.01.010, 2015.

Bellè, S. and Abiven, S.: Dataset to Manuscript: Key drivers of pyrogenic carbon redistribution during a simulated rainfall event, Zenodo, https://doi.org/10.5281/zenodo.4422514, 2021.

Berger, C., Schulze, M., Rieke-Zapp, D., and Schlunegger, F.: Rill development and soil erosion: A laboratory study of slope and rainfall intensity, Earth Surf. Processes, 35, 1456-1467, https://doi.org/10.1002/esp.1989, 2010.

Berhe, A. A. and Kleber, M.: Erosion, deposition, and the persistence of soil organic matter: Mechanistic considerations and problems with terminology, Earth Surf. Processes, 38, 908-912, https://doi.org/10.1002/esp.3408, 2013.

Berhe, A. A., Harte, J., Harden, J. W., and Torn, M. S.: The Significance of the Erosion-induced Terrestrial Carbon Sink, Bioscience, 57, 337-346, https://doi.org/10.1641/B570408, 2007.

Berhe, A. A., Harden, J. W., Torn, M. S., Kleber, M., Burton, S. D., and Harte, J.: Persistence of soil organic matter in eroding versus depositional landform positions, J. Geophys. Res.-Biogeo., 117, G02019, https://doi.org/10.1029/2011JG001790, 2012.

Berhe, A. A., Barnes, R. T., Six, J., and Marín-Spiotta, E.: Role of Soil Erosion in Biogeochemical Cycling of Essential Elements: Carbon, Nitrogen, and Phosphorus, Annu. Rev. Earth Pl. Sc., 46, 521-548, https://doi.org/10.1146/annurev-earth-082517010018, 2018

Bird, M. I., Wynn, J. G., Saiz, G., Wurster, C. M., and McBeath, A.: The Pyrogenic Carbon Cycle, Annu. Rev. Earth Pl. Sc., 43, 273-298, https://doi.org/10.1146/annurev-earth-060614105038, 2015.

Boot, C. M., Haddix, M., Paustian, K., and Cotrufo, M. F.: Distribution of black carbon in ponderosa pine forest floor and soils following the High Park wildfire, Biogeosciences, 12, 3029-3039, https://doi.org/10.5194/bg-12-3029-2015, 2015.

Bowman, D. M. J. S., Balch, J. K., Artaxo, P., Bond, W. J., Carlson, J. M., Cochrane, M. A., D’Antonio, C. M., DeFries, R. S., Doyle, J. C., Harrison, S. P., Johnston, F. H., Keeley, J. E., Krawchuk, M. A., Kull, C. A., Marston, J. B., Moritz, M. A., Prentice, I. C., Roos, C. I., Scott, A. C., Swetnam, T. W., van der Werf, G. R., 
and Pyne, S. J.: Fire in the Earth System, Science, 324, 481-484, https://doi.org/10.1126/science.1163886, 2009.

Braun, S., Tresch, S., and Augustin, S.: Soil solution in Swiss forest stands: A 20 year's time series, PLoS One, 15, e0227530, https://doi.org/10.1371/journal.pone.0227530, 2020.

Brewer, C. E., Chuang, V. J., Masiello, C. A., Gonnermann, H., Gao, X., Dugan, B., Driver, L. E., Panzacchi, P., Zygourakis, K., and Davies, C. A.: New approaches to measuring biochar density and porosity, Biomass Bioenerg., 66, 176-185, https://doi.org/10.1016/j.biombioe.2014.03.059, 2014.

Certini, G.: Effects of fire on properties of forest soils: a review, Oecologia, 143, 1-10, https://doi.org/10.1007/s00442-004-17888, 2005.

Chaplot, V. and Le Bissonnais, Y.: Runoff features for interrill erosion at different rainfall intensities, slope lengths, and gradients in an agricultural loessial hillslope, Soil Sci. Soc. Am. J., 67, 844-851, https://doi.org/10.2136/sssaj2003.8440, 2003.

Chaplot, V., Le Bissonnais, Y., and Bernadou, J.: Runoff, Soil, and Soil Organic Carbon Losses within a Small SlopingLand Catchment of Laos under Shifting Cultivation, in: Soil Erosion and Carbon Dynamics, 1st Edn., edited by: Roose, E. J., Lal, R., Feller, C., Barthés, B., and Steward, B. A., Taylor \& Francis Group, Boca Raton, 167-180, https://doi.org/10.1201/9780203491935, 2005.

Chappell, A., Baldock, J., and Sanderman, J.: The global significance of omitting soil erosion from soil organic carbon cycling schemes, Nat. Clim. Change, 6, 187-191, https://doi.org/10.1038/nclimate2829, 2016.

Chatterjee, S., Santos, F., Abiven, S., Itin, B., Stark, R. E., and Bird, J. A.: Elucidating the chemical structure of pyrogenic organic matter by combining magnetic resonance, mid-infrared spectroscopy and mass spectrometry, Org. Geochem., 51, 35-44, https://doi.org/10.1016/j.orggeochem.2012.07.006, 2012.

Christiansen, J. E.: Irrigation by Sprinkling - Bulletin 670, University of California, College of Agriculture, Agricultural Experiment Station, Berkeley, California, USA, 124 pp., 1942.

Chrzazvez, J., Théry-Parisot, I., Fiorucci, G., Terral, J. F., and Thibaut, B.: Impact of post-depositional processes on charcoal fragmentation and archaeobotanical implications: Experimental approach combining charcoal analysis and biomechanics, J. Archaeol. Sci., 44, 30-42, https://doi.org/10.1016/j.jas.2014.01.006, 2014.

Clarke, M. A. and Walsh, R. P. D.: A portable rainfall simulator for field assessment of splash and slopewash in remote locations, Earth Surf. Processes, 32, 2052-2069, https://doi.org/10.1002/esp, 2007.

Conard, S. G. and Solomon, A. M.: Effect of wildland fire on regional and global carbon stocks in a changing environment, in: Developments in Environmental Science, edited by: Bytnerowicz, A., Arbaugh, M., Riebau, A., and Andersen, C., Elsevier B.V., Oxford, https://doi.org/10.1016/S1474-8177(08)00005-3, 109-138, 2008

Coppola, A. I. and Druffel, E. R. M.: Cycling of black carbon in the ocean, Geophys. Res. Lett., 43, 4477-4482, https://doi.org/10.1002/2016GL068574, 2016.

Cotrufo, M. F., Boot, C., Kampf, S., Nelson, P. A., Brogan, D. J., Covino, T., Haddix, M., MacDonald, L. H., Rathburn, S., Ryan-Bukett, S., Schmeer, S., and Hall, E.: Redistribution of pyrogenic carbon from hillslopes to stream corridors following a large montane wildfire, Global Biogeochem. Cy., 30, 1348-1355, https://doi.org/10.1111/1462-2920.13280, 2016.

Crawford, A. J. and Belcher, C. M.: Charcoal Morphometry for Paleoecological Analysis: The Effects of Fuel Type and Transportation on Morphological Parameters, Appl. Plant Sci., 2, 1400004, https://doi.org/10.3732/apps.1400004, 2014.

DeBano, L. F.: The role of fire and soil heating on water repellency in wildland environments: a review, J. Hydrol., 231-232, 195206, https://doi.org/10.1016/S0022-1694(00)00194-3, 2000.

de Nijs, E. A. and Cammeraat, E. L. H.: The stability and fate of Soil Organic Carbon during the transport phase of soil erosion, Earth-Sci. Rev., 201, 103067, https://doi.org/10.1016/j.earscirev.2019.103067, 2020.

Doerr, S. H.: On standardizing the "water drop penetration time" and the "molarity of an ethanol droplet" techniques to classify soil hydrophobicity: a case study using medium textured soils, Earth Surf. Processes, 23, 663-668, https://doi.org/10.1002/(SICI)10969837(199807)23:7<663::AID-ESP909>3.0.CO;2-6, 1998.

Doetterl, S., Berhe, A. A., Nadeu, E., Wang, Z., Sommer, M., and Fiener, P.: Erosion, deposition and soil carbon: A review of process-level controls, experimental tools and models to address C cycling in dynamic landscapes, Earth-Sci. Rev., 154, 102-122, https://doi.org/10.1016/j.earscirev.2015.12.005, 2016.

Federal Office of Meteorology and Climatology MeteoSwiss: Swiss climate in detail, Extreme value analysis, available at: https://www.meteoswiss.admin.ch/home/ climate/swiss-climate-in-detail/extreme-value-analyses/ standard-period.html? (last access: 27 August 2020), 2019.

Fonseca, F., de Figueiredo, T., Nogueira, C., and Queirós, A.: Effect of prescribed fire on soil properties and soil erosion in a Mediterranean mountain area, Geoderma, 307, 172-180, https://doi.org/10.1016/j.geoderma.2017.06.018, 2017.

Galanter, A., Cadol, D., and Lohse, K.: Geomorphic influences on the distribution and accumulation of pyrogenic carbon (PyC) following a low severity wildfire in northern New Mexico, Earth Surf. Processes, 43, 2207-2218, https://doi.org/10.1002/esp.4386, 2018.

Giglio, L., Randerson, J. T., and van der Werf, G. R.: Analysis of daily, monthly, and annual burned area using the fourthgeneration global fire emissions database (GFED4), J. Geophys. Res.-Biogeo., 118, 317-328, https://doi.org/10.1002/jgrg.20042, 2013.

Güereña, D. T., Lehmann, J., Walter, T., Enders, A., Neufeldt, H., Odiwour, H., Biwott, H., Recha, J., Shepherd, K., Barrios, E., and Wurster, C.: Terrestrial pyrogenic carbon export to fluvial ecosystems: Lessons learned from the White Nile watershed of East Africa, Global Biogeochem. Cy., 29, 1911-1928, https://doi.org/10.1002/2015GB005095, 2015.

Hagedorn, F. H., Spinnler, D., Bundt, M., Blaser, P., and Siegwolf, R.: The input and fate of new $\mathrm{C}$ in two forest soils under elevated $\mathrm{CO}_{2}$, Global Change Biol., 9, 862-872, https://doi.org/10.1046/j.1365-2486.2003.00638.x, 2003.

Hammes, K. and Abiven, S.: Identification of Black Carbon in the Earth System, in: Fire Phenomena and the Earth System: An Interdisciplinary Guide to Fire Science, edited by: Belcher, C. M., John Wiley \& Sons, Ltd, Chichester UK, 157-176, https://doi.org/10.1002/9781118529539, 2013. 
Hammes, K., Smernik, R. J., Skjemstad, J. O., Herzog, A., Vogt, U. F., and Schmidt, M. W. I.: Synthesis and characterisation of laboratory-charred grass straw (Oryza sativa) and chestnut wood (Castanea sativa) as reference materials for black carbon quantification, Org. Geochem., 37, 1629-1633, https://doi.org/10.1016/j.orggeochem.2006.07.003, 2006.

Hilber, I., Blum, F., Leifeld, J., Schmidt, H. P., and Bucheli, T. D.: Quantitative determination of PAH's in biochar: A prerequisite to ensure its quality and safe application, J. Agr. Food Chem., 60, 3042-3050, https://doi.org/10.1021/jf205278v, 2012.

Hilscher, A. and Knicker, H.: Degradation of grass-derived pyrogenic organic material, transport of the residues within a soil column and distribution in soil organic matter fractions during a 28 month microcosm experiment, Org. Geochem., 42, 42-54, https://doi.org/10.1016/j.orggeochem.2010.10.005, 2011.

Iserloh, T., Fister, W., Seeger, M., Willger, H., and Ries, J. B.: A small portable rainfall simulator for reproducible experiments on soil erosion, Soil Till. Res., 124, 131-137, https://doi.org/10.1016/j.still.2012.05.016, 2012.

IUSS Working Group WRB: World Reference Base for Soil Resources, International soil classification systems for naming soils and creating legends for soil maps, Food and Agriculture Organization of the United Nations, Rome, Italy, available at: http://www.fao.org/soils-portal/soil-survey/soil-classification/ world-reference-base/en/ (last access: 23 March 2020), 2015.

Jian, M., Berhe, A. A., Berli, M., and Ghezzehei, T. A.: Vulnerability of physically protected soil organic carbon to loss under low severity fires, Front. Environ. Sci., 6, 66, https://doi.org/10.3389/fenvs.2018.00066, 2018.

Jiang, X., Haddix, M. L., and Cotrufo, M. F.: Interactions between biochar and soil organic carbon decomposition: Effects of nitrogen and low molecular weight carbon compound addition, Soil Biol. Biochem., 100, 92-101, https://doi.org/10.1016/j.soilbio.2016.05.020, 2016.

Jiang, X., Tan, X., Cheng, J., Haddix, M. L., and Cotrufo, M. F.: Interactions between aged biochar, fresh low molecular weight carbon and soil organic carbon after 3.5 years soil-biochar incubations, Geoderma, 333, 99-107, https://doi.org/10.1016/j.geoderma.2018.07.016, 2019.

Johansen, M. P., Hakonson, T. E., and Breshears, D. D.: Post-fire runoff and erosion from rainfall simulation: Contrasting forests with shrublands and grasslands, Hydrol. Process., 15, 29532965, https://doi.org/10.1002/hyp.384, 2001.

Jones, M. W., Santín, C., van der Werf, G. R., and Doerr, S. H.: Global fire emissions buffered by the production of pyrogenic carbon, Nat. Geosci., 12, 742-747, https://doi.org/10.1038/s41561-019-0403-x, 2019.

Kathiravelu, G., Lucke, T., and Nichols, P.: Rain drop measurement techniques: A review, Water, 8, 29, https://doi.org/10.3390/w8010029, 2016.

Keiluweit, M., Nico, P. S., Johnson, M., and Kleber, M.: Dynamic molecular structure of plant biomass-derived black carbon (biochar), Environ. Sci. Technol., 44, 1247-1253, https://doi.org/10.1021/es9031419, 2010.

Koiter, A. J., Owens, P. N., Petticrew, E. L., and Lobb, D. A.: The role of soil surface properties on the particle size and carbon selectivity of interrill erosion in agricultural landscapes, Catena, 153, 194-206, https://doi.org/10.1016/j.catena.2017.01.024, 2017.
Lal, R.: Soil Carbon Sequestration Impacts on Global Climate Change and Food Secruity, Science, 304, 1623-1627, https://doi.org/10.1126/science.1097396, 2004.

Lasslop, G., Coppola, A. I., Voulgarakis, A., Yue, C., and Veraverbeke, S.: Influence of Fire on the Carbon Cycle and Climate, Curr. Clim. Change Rep., 5, 112-123, https://doi.org/10.1007/s40641-019-00128-9, 2019.

Lassu, T. and Seeger, M.: Set-up and calibration of an indoor nozzle-type rainfall simulator for soil erosion studies, Land Degrad. Dev., 26, 604-612, https://doi.org/10.1002/ldr.2360, 2015.

Le Bissonnais, Y.: Aggregate stability and assessment of soil crustability and erodibility: I. Theory and methodology, Eur. J. Soil Sci., 67, 11-21, https://doi.org/10.1111/ejss.4_12311, 2016.

Legout, C., Leguédois, S., Le Bissonnais, Y., and Malam Issa, O.: Splash distance and size distributions for various soils, Geoderma, 124, 279-292, https://doi.org/10.1016/j.geoderma.2004.05.006, 2005.

Maestrini, B., Abiven, S., Singh, N., Bird, J., Torn, M. S., and Schmidt, M. W. I.: Carbon losses from pyrolysed and original wood in a forest soil under natural and increased $\mathrm{N}$ deposition, Biogeosciences, 11, 5199-5213, https://doi.org/10.5194/bg-115199-2014, 2014.

Major, J., Lehmann, J., Rondon, M., and Goodale, C.: Fate of soil-applied black carbon: Downward migration, leaching and soil respiration, Global Change Biol., 16, 1366-1379, https://doi.org/10.1111/j.1365-2486.2009.02044.x, 2010.

Malam Issa, O., Le Bissonnais, Y., Planchon, O., Favis-Mortlock, D., Silvera, N., and Wainwright, J.: Soil detachment and transport on field- and laboratory-scale interrill areas: Erosion processes and the size-selectivity of eroded sediment, Earth Surf. Processes, 31, 929-939, https://doi.org/10.1002/esp.1303, 2006.

Malvar, M. C., Martins, M. A. S., Nunes, J. P., Robichaud, P. R., and Keizer, J. J.: Assessing the role of pre-fire ground preparation operations and soil water repellency in post-fire runoff and inter-rill erosion by repeated rainfall simulation experiments in Portuguese eucalypt plantations, Catena, 108, 69-83, https://doi.org/10.1016/j.catena.2012.11.004, 2013.

Masiello, C. A.: New directions in black carbon organic geochemistry, Mar. Chem., 92, 201-213, https://doi.org/10.1016/j.marchem.2004.06.043, 2004.

Masiello, C. A. and Berhe, A. A.: First Interactions with the Hydrologic Cycle Determine Pyrogenic Carbon's Fate in the Earth System, Earth Surf. Processes, 45, 2394-2398, https://doi.org/10.1002/esp.4925, 2020.

McCorkle, E. P., Berhe, A. A., Hunsaker, C. T., Johnson, D. W., McFarlane, K. J., Fogel, M. L., and Hart, S. C.: Tracing the source of soil organic matter eroded from temperate forest catchments using carbon and nitrogen isotopes, Chem. Geol., 445, 172-184, https://doi.org/10.1016/j.chemgeo.2016.04.025, 2016.

Moody, J. A., Shakesby, R. A., Robichaud, P. R., Cannon, S. H., and Martin, D. A.: Current research issues related to postwildfire runoff and erosion processes, Earth-Sci. Rev., 122, 1037, https://doi.org/10.1016/j.earscirev.2013.03.004, 2013.

Moragues-Saitua, L., Arias-González, A., and GartziaBengoetxea, N.: Effects of biochar and wood ash on soil hydraulic properties: A field experiment involving contrasting temperate soils, Geoderma, 305, 144-152, https://doi.org/10.1016/j.geoderma.2017.05.041, 2017. 
Onda, Y., Dietrich, W. E., and Booker, F.: Evolution of overland flow after a severe forest fire, Point Reyes, California, Catena, 72, 13-20, https://doi.org/10.1016/j.catena.2007.02.003, 2008.

Pierson, F. B., Jason Williams, C., Hardegree, S. P., Clark, P. E., Kormos, P. R., and Al-Hamdan, O. Z.: Hydrologic and erosion responses of sagebrush steppe following juniper encroachment, wildfire, and tree cutting, Rangeland Ecol. Manag., 66, 274-289, https://doi.org/10.2111/REM-D-12-00104.1, 2013.

Pignatello, J. J., Uchimiya, M., Abiven, S., and Schmidt, M. W. I.: Evolution of biochar properties in soil, in: Biochar for Environmental Management - Science, Technology and Implementation, edited by: Lehmann, J. and Joseph, S., Taylor \& Francis Group, London, 195-233, https://doi.org/10.4324/9780203762264, 2015.

Poeplau, C., Vos, C., and Don, A.: Soil organic carbon stocks are systematically overestimated by misuse of the parameters bulk density and rock fragment content, SOIL, 3, 61-66, https://doi.org/10.5194/soil-3-61-2017, 2017.

Proulx, R., Rheault, G., Bonin, L., Roca, I. T., Martin, C. A., Desrochers, L., and Seiferling, I.: How much biomass do plant communities pack per unit volume?, PeerJ, 3, e849, https://doi.org/10.7717/peerj.849, 2015.

Pyle, L. A., Magee, K. L., Gallagher, M. E., Hockaday, W. C., and Masiello, C. A.: Short-Term Changes in Physical and Chemical Properties of Soil Charcoal Support Enhanced Landscape Mobility, J. Geophys. Res.-Biogeo., 122, 3098-3107, https://doi.org/10.1002/2017JG003938, 2017.

$\mathrm{R}$ Core Team: A language and environment for statistical computing, R Foundation for Statistical Computing, Vienna, Austria, available at: https://www.R-project.org/ (last access: 1 January 2020), 2020.

Randerson, J. T., Chen, Y., van der Werf, G. R., Rogers, B. M., and Morton, D. C.: Global burned area and biomass burning emissions from small fires, J. Geophys. Res.-Biogeo., 117, G04012, https://doi.org/10.1029/2012JG002128, 2012.

Reisser, M., Purves, R. S., Schmidt, M. W. I., and Abiven, S.: Pyrogenic Carbon in Soils: A Literature-Based Inventory and a Global Estimation of Its Content in Soil Organic Carbon and Stocks, Front. Earth Sci., 4, 80, https://doi.org/10.3389/feart.2016.00080, 2016.

Robichaud, P. R., Wagenbrenner, J. W., Pierson, F. B., Spaeth, K. E., Ashmun, L. E., and Moffet, C. A.: Infiltration and interrill erosion rates after a wildfire in western Montana, USA, Catena, 142, 77-88, https://doi.org/10.1016/j.catena.2016.01.027, 2016.

Ruehr, N. K., Knohl, A., and Buchmann, N.: Environmental variables controlling soil respiration on diurnal, seasonal and annual time-scales in a mixed mountain forest in Switzerland, Biogeochemistry, 98, 153-170, https://doi.org/10.1007/s10533-0099383-z, 2010.

Rumpel, C., Chaplot, V., Planchon, O., Bernadou, J., Valentin, C., and Mariotti, A.: Preferential erosion of black carbon on steep slopes with slash and burn agriculture, Catena, 65, 30-40, https://doi.org/10.1016/j.catena.2005.09.005, 2006.

Rumpel, C., Ba, A., Darboux, F., Chaplot, V., and Planchon, O.: Erosion budget and process selectivity of black carbon at meter scale, Geoderma, 154, 131-137, https://doi.org/10.1016/j.geoderma.2009.10.006, 2009.

Rumpel, C., Leifeld, J., Santin, C., and Doerr, S.: Movement of biochar in the environment, in: Biochar for Environmental Man- agement - Science, Technology and Implementation, edited by: Lehmann, J. and Joseph, S., Taylor \& Francis Group, London, 281-298, https://doi.org/10.4324/9780203762264, 2015.

Saiz, G., Goodrick, I., Wurster, C., Nelson, P. N., Wynn, J., and Bird, M.: Preferential Production and Transport of Grass-Derived Pyrogenic Carbon in NE-Australian Savanna Ecosystems, Front. Earth Sci., 5, 115, https://doi.org/10.3389/feart.2017.00115, 2018.

Santín, C., Doerr, S. H., Preston, C. M., and González-Rodríguez, G.: Pyrogenic organic matter production from wildfires: a missing sink in the global carbon cycle, Global Change Biol., 21, 1621-1633, https://doi.org/10.1111/gcb.12800, 2015.

Santín, C., Doerr, S. H., Kane, E. S., Masiello, C. A., Ohlson, M., de la Rosa, J. M., Preston, C. M., and Dittmar, T.: Towards a global assessment of pyrogenic carbon from vegetation fires, Global Change Biol., 22, 76-91, https://doi.org/10.1111/gcb.12985, 2016.

Schindler Wildhaber, Y., Bänninger, D., Burri, K., and Alewell, C.: Evaluation and application of a portable rainfall simulator on subalpine grassland, Catena, 91, 56-62, https://doi.org/10.1016/j.catena.2011.03.004, 2012.

Shakesby, R. A.: Post-wildfire soil erosion in the Mediterranean: Review and future research directions, Earth-Sci. Rev., 105, 71100, https://doi.org/10.1016/j.earscirev.2011.01.001, 2011.

Shakesby, R. A. and Doerr, S. H.: Wildfire as a hydrological and geomorphological agent, Earth-Sci. Rev., 74, 269-307, https://doi.org/10.1016/j.earscirev.2005.10.006, 2006.

Shakesby, R. A., Bento, C. P. M., Ferreira, C. S. S., Ferreira, A. J. D., Stoof, C. R., Urbanek, E., and Walsh, R. P. D.: Impacts of prescribed fire on soil loss and soil quality: An assessment based on an experimentallyburned catchment in central Portugal, Catena, 128, 278-293, https://doi.org/10.1016/j.catena.2013.03.012, 2015.

Singh, N., Abiven, S., Torn, M. S., and Schmidt, M. W. I.: Fire-derived organic carbon in soil turns over on a centennial scale, Biogeosciences, 9, 2847-2857, https://doi.org/10.5194/bg9-2847-2012, 2012.

Singh, N., Abiven, S., Maestrini, B., Bird, J. A., Torn, M. S., and Schmidt, M. W. I.: Transformation and stabilization of pyrogenic organic matter in a temperate forest field experiment, Global Change Biol., 20, 1629-1642, https://doi.org/10.1111/gcb.12459, 2014.

Soucémarianadin, L., Reisser, M., Cécillon, L., Barré, P., Nicolas, M., and Abiven, S.: Pyrogenic carbon content and dynamics in top and subsoil of French forests, Soil Biol. Biochem., 133, 12 15, https://doi.org/10.1016/j.soilbio.2019.02.013, 2019.

Spokas, K. A., Novak, J. M., Masiello, C. A., Johnson, M. G., Colosky, E. C., Ippolito, J. A., and Trigo, C.: Physical Disintegration of Biochar: An Overlooked Process, Environ. Sci. Tech. Let., 1, 326-332, https://doi.org/10.1021/ez500199t, 2014.

Stallard, R. F.: Terrestrial sedimentation and the carbon cycle: Coupling weathering and erosion to carbon burial, Global Biogeochem. Cy., 12, 231-257, https://doi.org/10.1029/98GB00741, 1998.

Stoof, C. R., Gevaert, A. I., Baver, C., Hassanpour, B., Morales, V. L., Zhang, W., Martin, D., Giri, S. K., and Steenhuis, T. S.: Can pore-clogging by ash explain post-fire runoff?, Int. J. Wildland Fire, 25, 294-305, https://doi.org/10.1071/WF15037, 2016. 
Thomaz, E. L.: Interaction between ash and soil microaggregates reduces runoff and soil loss, Sci. Total Environ., 625, 1257-1263, https://doi.org/10.1016/j.scitotenv.2018.01.046, 2018.

Tinner, W., Hofstetter, S., Zeugin, F., Conedera, M., Wohlgemuth, T., Zimmermann, L., and Zweifell, R.: Long-distance transport of macroscopic charcoal by an intensive crown fire in the Swiss Alps - implications for fire history reconstruction, Holocene, 16, 287-292, https://doi.org/10.1191/0959683606h1925rr, 2006.

van der Werf, G. R., Randerson, J. T., Giglio, L., van Leeuwen, T. T., Chen, Y., Rogers, B. M., Mu, M., van Marle, M. J. E., Morton, D. C., Collatz, G. J., Yokelson, R. J., and Kasibhatla, P. S.: Global fire emissions estimates during 1997-2016, Earth Syst. Sci. Data, 9, 697-720, https://doi.org/10.5194/essd-9-697-2017, 2017.

Vieira, D. C. S., Fernández, C., Vega, J. A., and Keizer, J. J.: Does soil burn severity affect the post-fire runoff and interrill erosion response? A review based on meta-analysis of field rainfall simulation data, J. Hydrol., 523, 452-464, https://doi.org/10.1016/j.jhydrol.2015.01.071, 2015.
Vieira, D. C. S., Malvar, M. C., Martins, M. A. S., Serpa, D., and Keizer, J. J.: Key factors controlling the post-fire hydrological and erosive response at micro-plot scale in a recently burned Mediterranean forest, Geomorphology, 319, 161-173, https://doi.org/10.1016/j.geomorph.2018.07.014, 2018.

Wang, Z., Govers, G., Steegen, A., Clymans, W., van der Putte, A., Langhans, C., Merckx, R., and van Oost, K.: Catchmentscale carbon redistribution and delivery by water erosion in an intensively cultivated area, Geomorphology, 124, 65-74, https://doi.org/10.1016/j.geomorph.2010.08.010, 2010.

Westerling, A. L., Hidalgo, H. G., Cayan, D. R., and Swetnam, T. W.: Warming and earlier spring increase Western US forest wildfire activity, Science, 313, 940-943, https://doi.org/10.1126/science.1128834, 2006. 